Article

\title{
Exploring the Role of Advertising Types on Improving the Water Consumption Behavior: An Application of Integrated Fuzzy AHP and Fuzzy VIKOR Method
}

\author{
Amir Hossein Salimi ${ }^{1}{ }^{\oplus}$, Amir Noori $^{2}$, Hossein Bonakdari $^{3}{ }^{\circledR}$, Jafar Masoompour Samakosh ${ }^{4}(\mathbb{C}$, \\ Ehsan Sharifi ${ }^{5,6, *(D)}$, Mohammadreza Hassanvand ${ }^{1}$, Baharam Gharabaghi ${ }^{7}$ (D) and \\ Mehdi Agharazi ${ }^{8}$ \\ 1 Department of Civil Engineering, Semnan University, Semnan 35131, Iran; \\ amirhsalimi@semnan.ac.ir (A.H.S.); mohammadrezahassanvand@semnan.ac.ir (M.H.) \\ 2 Department of Civil Engineering, Razi University, Kermanshah 67146, Iran; noori.amir@stu.razi.ac.ir \\ 3 Department of Soils and Agri-Food Engineering, Laval University, Quebec City, QC G1V0A6, Canada; \\ hossein.bonakdari@fsaa.ulaval.ca \\ 4 Department of climatology, Razi University, Kermanshah 67146, Iran; j.masoompour@razi.ac.ir \\ 5 Institute of Meteorology and Climatology, University of Natural Resources and Life Sciences (BOKU), \\ 1180 Vienna, Austria \\ 6 Section 4.4 Hydrology, GFZ German Research Centre for Geosciences, 14473 Potsdam, Germany \\ 7 School of Engineering, University of Guelph, Guelph, ON N1G 2W1, Canada; bgharaba@uoguelph.ca \\ 8 Departemant of Industrial Engineering, Islamic Azad University of NajafAbad, \\ 8514143131 NajafAbad, Isfahan, Iran; mehdi.agharazi@gmail.com \\ * Correspondence: ehsan.sharifi@gfz-potsdam.de; Tel.: +49-331-288-1588
}

Received: 30 December 2019; Accepted: 6 February 2020; Published: 8 February 2020

check for updates

\begin{abstract}
In recent years, many cities have suffered from a shortage of drinking water, mainly due to population growth. Hence, the desire to curb undue water consumption through the identification of the main factors affecting consumer behavior has become very important in managing drinking water supplies. Modifying the consumption pattern means institutionalizing of a sustainable culture in water consumption among consumers and the identification of the main criteria affecting their behavior. In 2018, a survey was applied to examine the role of mass media advertising in modifying the water consumption pattern in Iran. An integration of fuzzy AHP and fuzzy VIKOR was proposed based on group decision making, and fuzzy trapezoidal sets used to model linguistic variables and to deal with uncertainty in opinions. We devised and conducted a questionnaire with 24 main criteria and 8 sub-criteria to measure the impact of advertising on water consumption. The case study population in this study included all urban households over 15 cities of Iran. A total of 5630 questionnaires were distributed among the various populations with cluster method. Then, by analyzing the results, advertisements using animation had the highest impact on consumer behavior, among the available alternatives, and could play a significant role in modifying the water consumption pattern. Additionally, a fuzzy evaluation technique is performed to validate the result of the applied method. Subsequently, a sensitivity analysis was conducted to validate the stability of the final ranking. Finally, the prioritization results of the types of advertising by the proposed method were compared with the results of the fuzzy AHP method.
\end{abstract}

Keywords: consumption pattern modification; mass media; AHP; VIKOR; group decision making; trapezoidal fuzzy set 


\section{Introduction}

The freshwater shortage is a global issue, and most countries all over the world are approaching the water scarcity problem and related difficulties [1-8]. Urban water supply is one of the most sensitive and important types of water uses because of health problems and basic human needs for water, and the probability of social tensions [9-11].

However, the amount of urban water use depends on several factors such as patterns and habits of water use by the population, etc. During the last century, due to the rapid growth of population, economic development, agricultural growth, increasing awareness of the imminent changes in the regional climate, especially for developing countries in the Middle East, that changing water consumption patterns are needed $[12,13]$. Furthermore, in urban areas, especially in arid and semi-arid regions, access to sustainable water resources is critical. Therefore, determining the factors that affect the water consumption behavior is very important in water resources management [11]. Iran is also located in an arid and semi-arid climate with annual average precipitation of $250 \mathrm{~mm}$ [11,14]. However, according to the Statistical Centre of Iran (SCI), Iran's population has increased six fold over the past century, and only in the period of 2006 to 2011, about 9.5 million people have been added to the population. As a result, increasing domestic and sanitary water consumption and the emergence of new water demands to improve living standards of people have led to an accelerated increase in the cost of water supplies needed. Therefore, due to different climatic and geographical conditions of the region and the increasing demands of water, to make a balance between the water supply and demand, it is necessary to present an integrated management model to modify the water consumption pattern.

\subsection{Advertising and Consumption}

Advertising has a very strong influence on determining an appropriate consumption pattern among consumers. Various types of advertising, such as television (TV) and radio advertising, city buses and billboards advertising, and internet advertising, attack us every day. The media, especially television, have vast capabilities and abilities for training at all levels and fields, and its educational function includes all forms and media materials. What needs to be emphasized in the field of media education is to equip the audience with tools for the understanding and processing of messages and media information [15]. One of the suitable ways to change people's habits in modifying the consumption pattern is an advertisement (ADVT).

Communication with existing and potential consumers is critical to any organization and business entity that seeks to succeed in attracting and changing consumer attitudes [16]. Although advertising as an effective strategic communication program cannot guarantee success, it certainly increases the chance of it. Therefore, advertising should be considered as an essential tool to maintain an impact on consumer behavior, since it has been already proven that most people only pay attention to the materials and consequences, which are indicated in the media.

\subsection{Decision-Making Techniques}

In recent years, the use of decision-making techniques has been enhanced to solve complex problems in which there are several quantitative and qualitative criteria. Overall, most of the criteria conflict with each other [17]. For this reason, several methods have been developed called Multi-Criteria Decision-Making (MCDM) that help to solve these problems [18]. The MCDMs have various techniques in different decision-making stages. In these methods, based on mathematical reasoning, several alternatives are compared based on several different criteria; the best alternative or arrangement of the appropriate alternatives is chosen [19]. Various methods of MCDM are proposed to solve decision problems [20-22]. Different techniques originating from MCDM include Analytic Hierarchy Process (AHP) [23], Technique for Order Preference by Simulation of Ideal Solution (TOPSIS) [24,25], ELimination and Choice Expressing REality (ELECTRE) [26], Analytic Network Process (ANP) [27,28], Vise Kriterijumska Optimizacija I Kompromisno Resenje (VIKOR) [29], and the Preference Ranking 
Organisation MeTHod for Enrichment Evaluations (PROMETHEE) [30]. Hence, using these methods will help researchers to create and improve the results of scientific research in many fields, including social sciences, medicine, engineering, computer science, and information management [31-33].

AHP $[22,34]$ presents a MCDM method for solving problems with prioritization. AHP uses objective mathematics to process individual or group preferences in decision-making [35]. AHP is one of the most well-known MCDM techniques. The AHP method is based on paired comparisons that can be used when decision-making practice comes with several alternatives and quantitative and qualitative criteria [22,34]. Classical method of MCDM such as AHP cannot function effectively in dealing with information containing uncertainty.

The VIKOR method is developed by Opricovic and Tzeng (2004) to solve MCDM problems with conflicting and uncertain criteria [36,37]. The VIKOR as the appropriate compromised ranking method uses a simple computation procedure to determine the closest ideal solution among the alternatives for all criteria in a complex multi-criteria system optimization [36]. This method concentrates on ranking and selecting from a set of other alternatives in the presence of conflicting criteria, and on proposing a compromise solution [38]. Compromise solution is a feasible solution for all decision makers that are closest to the ideal solution [38]. Using such a compromise solution, VIKOR introduces the multi-criteria ranking indices to evaluate the maximum 'group utility of the majority' and the minimum 'individual regret of the opponent' [39]. The fuzzy VIKOR method is presented by Opricovic and Tzeng (2007) as a fuzzy MCDM method in order to enhance the performance of method and solve a multi-criteria problem with conflicting criteria under an uncertain environment $[38,39]$.

However, in this study, due to the dependence of decision-making issues on different quantitative and qualitative criteria and the existence of uncertainty in opinions, decision-making is often a complex task. Hence, to overcome the ambiguity and uncertainty in decisions, in this study, the proposed method combined with fuzzy logic. Therefore, the fuzzy AHP and fuzzy VIKOR employed in this paper are based on Trapezoidal fuzzy sets to prevent uncertainty in assessing linguistic variables. Trapezoidal fuzzy sets are among the simplest methods for processing of the data [40]. This fuzzy set is widely used to express the importance of criteria according to linguistic expressions [41].

\subsection{Literature Review}

\subsubsection{Previous Studies Related to the Effective Criteria of Water Consumption}

Identifying the effective criteria of water consumption and consumer behavior to manage water resources in a region is critical. In the following, some similar activities that were carried out in different parts of the world were mentioned. Popkin et al. (2005) investigated water use and food consumption patterns among adults during the years 1999-2001. They examined the sociological characteristics of food and water consumption patterns using a multinomial logit analysis [42]. Keshavarzi et al. (2006) investigated the relationship between water use, rural households' activities, and factors affecting water consumption using a simple random sampling method between 1999-2004 [43]. Jones et al. (2007) described patterns for drinking water consumption in British Columbia, Canada. They examined the relationship between water use patterns with various demographic factors and digestive diseases [44]. Harlan et al. (2009) examined in a household social survey the individual water consumption for 24 months of individually metered water usage records for single-family houses. They determined water consumption is affected by income, household amenities, or attitudes toward community and the environment mediate [45]. Islam et al. (2011) investigated water supply scarcity and water consumption behavior in two southwestern coastal districts of Bangladesh based on a simple random sampling technique. They used a survey from 750 rural households in 39 villages of southwest coastal regions of Bangladesh [46]. Shan et al. (2015) determined the behavior of household water consumption to address the amount of water usage within the home in the European Union (EU) using a survey in Greece and Poland. The results including an analysis of three main elements related to the behavior of household water consumers are as follows: (i) End-use behaviors; (ii) sociological features and 
property characteristics; and (iii) psychological structures such as attitudes and beliefs [47]. In another study, Wright et al. (2018) informed people about the use of urban freshwater and identified the factors associated with water in the Inuit community. The categorized data from 2012 to 2014 was used in this study. To collect data, various variables related to water awareness were utilized by analyzing the Principal component analysis (PCA), and logistic regression was used to identify the variables related to water consumption patterns. In this study, women consumed drinking water more than men, and the average amount of water consumed per-day was 1 liter. The results of this study may indicate drinking water interventions, risk assessment, and public health messages in other native communities [48].

\subsubsection{Previous Studies Related to Advertising and Consumer Behavior}

The following is a brief summary of several studies on the role of advertising in water consumer behavior. Breuer et al. (2011) analyzed the long-term effects of different types of online advertising channels. They found advertising by email; banner and price comparison advertising have the longest effect, respectively. They also realized that the length of the effectiveness does not always match its intensity [49]. In another study, Hsieh et al. (2011) concentrated on the different influences of the information types on the internet advertising attention of the viewers [50]. Amoateng and Poku (2012) examined the impact of advertising on alcohol consumption, employing regression analysis. They assessed the nature of advertisements for alcoholic drinks to determine the factors affecting the use of alcoholic beverages as well as the relationship between advertisements and consumers. They found that people with a younger age group were more affected by advertising [51]. Srikanth et al. (2013) presented a conceptual framework for analyzing the impact of advertising on consumers using celebrities in India. They also believe that the advertisements advertised by celebrities are more appealing than other advertisements [52]. Ramkumar et al. (2014), in a real-life case study, identified 26 driving criteria and analyzed six major dimensions to manage sustainable purchasing programs using a hybrid MCDM model based on ANP and Liberatore score [53]. Nomura and Mitsukura (2015) investigated the effects of Electroencephalogram (EEG)-based television advertising. The results showed that there was a strong correlation between excitement and consumers' stress as they were watching commercials on popular TV channels, with words that could be remembered even after one month [54]. Gilbert et al. (2017), in a randomized study, examined the impact of food advertisements on children. They found that children used some food from the advertisements that were recently broadcast than older advertisements [55]. Wang et al. (2018) investigated the impact of healthy eating advertising on demand for healthy and unhealthy foods. The results indicated a distinction between consumers in terms of weight in the understanding of the effects of the advertising content on food and beverage demand. Among overweight people, anti-obesity advertising was more effective than an advertisement for reducing the demand for unhealthy food [56].

\subsubsection{Background of the Studies Related to the Proposed Method}

Numerous studies have been conducted to improve the AHP method and solve the uncertainty problems based on fuzzy sets. Van Laarhoven and Pedrycz (1983) performed the first study based on fuzzy sets that led to the integration of the AHP method with fuzzy logic [57]. Afterward, Buckley (1985) used trapezoidal fuzzy numbers to expand the AHP method. Moreover, he used the geometric mean method to determine the final weight of the fuzzy matrix for each alternative [58]. Chang (1996) developed the AHP method and solved the uncertainty problems based on fuzzy sets [59]. In another study, Cheng (1997) presented a new algorithm for naval tactical missile systems to be evaluated with AHP, where by calculating the final weights based on the entropy method, a systematic and practical program was presented for missile systems [60]. Deng (1999) introduced a fuzzy approach to handle the problems of MCDM methods in a simple way [61]. Csutora and Buckley (2001) presented a new method of finding fuzzy weights as direct fuzzification [62]. Wang and Chin (2006) presented a method to normalize fuzzy weights, and the final weight of a fuzzy comparison matrix was obtained using the 
AHP method [63]. In recent years, Fuzzy AHP decision-making methods have been considered by researchers in different fields of decision science [64-66].

In the literature, some researchers have improved the VIKOR method: Liou et al. (2010) applied the VIKOR method for improving the quality of domestic airlines' service [67]. Sanayei et al. (2010) used the VIKOR method to choose the best supplier in fuzzy sets [68]. Ying-yu and De-jian (2011) extended the VIKOR method for decision making problems with ratings of alternatives [69]. Tiwari et al. (2016) developed a modified VIKOR method with interval numbers to identify the best product design concept by considering cost and benefit characteristics of design criteria [70]. Opricovic (2011) applied fuzzy VIKOR for water resources, planning to development of a reservoir system for the Mlava River and to validate the fuzzy VIKOR procedure with the real world application [39]. Yücenur and Demirel (2012) extended VIKOR method based on a group decision-making process for an insurance company selection problem in Turkey under fuzzy environment [36]. Shemshadi et al. (2011) used fuzzy VIKOR based on entropy measure for the supplier selection process, and they obtained the decision makers' opinions in the form of linguistic terms, and then the linguistic terms were converted into trapezoidal fuzzy numbers, and the entropy concept was used for assigning the weights of the criteria [71]. Wang and Chang (2005) utilized fuzzy VIKOR as a resolution to deal with group MCDM problems [72]. Chang and Hsu (2009) adopted the VIKOR method for prioritizing land-use restraint strategies in the Tseng-Wen reservoir watershed [73]. San Cristóbal (2011) utilized the VIKOR method to choose a renewable energy project in Spain [74]. Kavita (2011) extended the VIKOR method in a fuzzy environment for robot selection [75]. Hence, VIKOR has been widely used in various areas of decision-making because of its unique superiority.

Moreover, many studies have made use of the combination of AHP and VIKOR. For example, Kaya and Kahraman (2010) used an integrated fuzzy VIKOR and AHP methodology for multi-criteria renewable energy planning in Istanbul [76]. Zhu et al. (2015) applied an integrated AHP and VIKOR for design concept evaluation based on rough numbers, to deal with ambiguity in decision-making. They conducted AHP to determine the weight of each evaluation criterion, and then used the VIKOR to evaluate the design concept alternatives [77]. In another study, Singh et al. (2015) applied a hierarchal MCDM method by combining AHP and VIKOR methods under interval-valued fuzzy environment to deal with sustainability strategy selection problems in manufacturing organizations [78]. Rezaie et al. (2014) proposed an intelligent MCDM approach to evaluate the performance of Iranian cement firms using an integrated fuzzy AHP-VIKOR method [79]. Kaya and Kahraman (2011) made the forestry decision making based on an integrated VIKOR and AHP approach [80]. Zamani et al. (2014) proposed a hybrid method by combining AHP and VIKOR under fuzzy environment for contractor selection [81]. Pourebrahim et al. (2014) applied an integrated VIKOR-Fuzzy AHP method to make a selection among criteria and alternatives for conservation development in a coastal area of Khuzestan district in Iran. In their study, they used Fuzzy AHP to determine the weights of the criteria, and then, VIKOR was adopted to find the importance of each criterion and determine a priority assessment for conservation among different locations [82]. Fu et al. (2014) used fuzzy AHP and VIKOR for benchmarking analysis in the hotel industry. During the procedure, the fuzzy AHP was applied to calculate the weights of the individual performance criteria. Then, the VIKOR technique was used to analyze the strategies [83]. In another paper, Mohaghar et al. (2012) introduce a combined Fuzzy AHP and VIKOR approach for selecting a marketing strategy. In this integrated approach, Fuzzy AHP is used to determine the fuzzy weights of criteria and sub-criteria, and VIKOR also aimed to rank strategies with respect to the sub-criteria [84]. Awasthi et al. (2018) used an integrated fuzzy AHP-VIKOR approach-based framework for sustainable global supplier selection. They applied fuzzy AHP to generate criteria weights for sustainable global supplier selection, and used fuzzy VIKOR to rank supplier performances [85]. 


\subsection{Outline of the Current Study}

In the present study, a combination of Fuzzy AHP and fuzzy VIKOR methods based on trapezoidal fuzzy sets was applied to perform a multi-criteria solution among four alternatives for investigating the role of advertising in modifying the water consumption pattern, such as the use of animation in television advertising, advertising by celebrities, and advertising in social networks. In this paper, the integrated method mainly contains two parts: First, using fuzzy AHP for the weighting of criteria, then using the Fuzzy VIKOR for a priority assessment of different advertising types with respect to all the criteria.

The knowledge of how water is currently used and the identification of factors affecting consumers' behavior have become very important in managing drinking water resources [43]. Hence, water resources management with the help of reforming the consumption pattern and examining consumers' behavior is among the most critical issues in Iran that needs further work to tackle such a crisis. On the other hand, according to the previous studies on the effectiveness of advertising, there is a discussion gap between examining the role of different types of advertising with respect to modifying the pattern of water consumption. Nevertheless, due to the high importance of water resources management, to our knowledge, only a few studies have been conducted to address this issue by modifying the water consumption pattern. Moreover, uncertainty about the effectiveness of advertising on water consumer behavior and the fact that the fuzzy VIKOR has never been used in the field of the water consumption pattern issue raised the motivation for conducting this research. Therefore, this study aims to reduce this gap using a group decision-making approach by utilization of different people's opinions.

In addition, the present research is a qualitative approach, and applied research that has been conducted in a survey method. The information was collected using a questionnaire, which was based on the research objectives. Therefore, using the fuzzy evaluation of values in the trapezoidal fuzzy number framework, the importance of qualitative criteria and identifying the most effective alternative for modifying consumption patterns can be calculated. The main questions of this study include examining the research hypotheses "there is an association between assumptions and modifying the pattern of consumption", the role of each criterion in modifying the pattern of consumption, the nature of the advertising types in changing the behavior of consumers, and finding the most effective advertising method, as well, which tried to be answered. The overall structure of this paper is as follows: In Section 2, the materials and methods of the research are discussed. In Section 3, the analysis of the obtained results from the proposed method are discussed, Section 4 is discussion, and lastly, in Section 5 , the conclusion of the research is presented.

\section{Materials and Methods}

\subsection{Study Area}

Iran is located in Southwest Asia between $25^{\circ}$ and $40^{\circ}$ north latitudes and $44^{\circ}$ and $63^{\circ}$ east longitudes. This country is characterized by an arid and semi-arid climate, with an area of about $1,648,000$ square kilometers [11]. Generally, the extensive latitude of the country and high elevation difference due to the high mountains (the Alborz Mountains in the north and the Zagros range in the west and south) and numerous low lying areas in the vicinity of the Persian Gulf, Oman Sea, and the Caspian Sea have led to different climatic conditions from arid to humid across the whole country [86]. Although the long-term average precipitation in Iran is about $250 \mathrm{~mm} / \mathrm{yr}$ [11], these various climates have caused the variable spatial and temporal distribution of precipitation in the country. The statistical population of the present study is the household population of 15 cities applying for the implementation of the plan based on the 2011 census in Iran [87]. Figure 1 shows the dispersion of cities in the statistical population. 


\subsection{Questionnaire Design Method}

To answer the issue raised in this study, by study literature and holding numerous meetings with experts in this field, several criteria were considered for each assumption. Finally, 24 main criteria and 8 sub-criteria were selected for inclusion in a questionnaire. Referring to Table 1 , this questionnaire has five dimensions used to design it from different theories (planting, highlighting, social learning, culture, and learning theory); in Table 2, the number of criteria related to each dimension is presented. The purpose of this questionnaire is to investigate the role of advertising on modifying the pattern of water consumption (advertising using animation, celebrities, advertising in social networks).

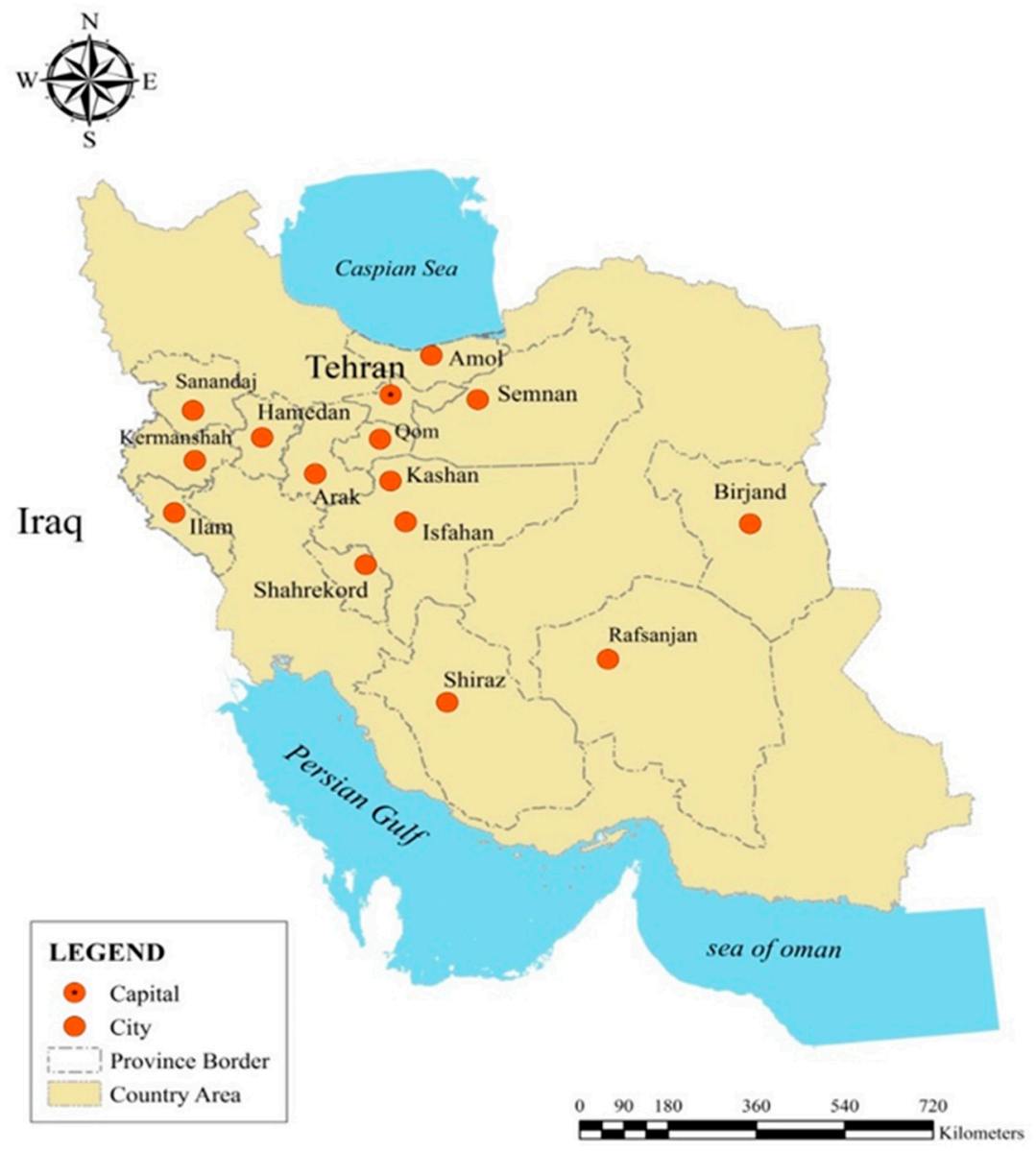

Figure 1. City dispersion map in the statistical society.

Table 1. The Effective criteria for modification of water consumption.

\begin{tabular}{cccc}
\hline Criteria & Description & Criteria & Description \\
\hline$C_{1}$ & $\begin{array}{c}\text { Persistence in the mind of } \\
\text { promotional animations }\end{array}$ & $\mathrm{C}_{17}$ & $\begin{array}{c}\text { Submitting social networking ADVTs to } \\
\text { friends and acquaintances } \\
\text { Watching more advertising usage } \\
\text { through social networks }\end{array}$ \\
$\mathrm{C}_{2}$ & $\begin{array}{c}\text { The magnetism of playing animations } \\
\text { in mass media }\end{array}$ & $\mathrm{C}_{18}$ & $\begin{array}{c}\text { The great influence of organizing } \\
\text { various media competitions } \\
\text { on audiences }\end{array}$ \\
$\mathrm{C}_{3}$ & $\begin{array}{c}\text { Simple communication with animated } \\
\text { ADVTs. Optimal water consumption }\end{array}$ & $\mathrm{C}_{19}$ & $\begin{array}{c}\text { Promoting effective celebration of } \\
\text { special events such as world water day } \\
\text { by the mass media }\end{array}$ \\
\hline
\end{tabular}


Table 1. Cont.

\begin{tabular}{|c|c|c|c|}
\hline Criteria & Description & Criteria & Description \\
\hline $\mathrm{C}_{5}$ & $\begin{array}{l}\text { The longevity of most of the spread } \\
\text { animated ADVTs }\end{array}$ & $\mathrm{C}_{21}$ & $\begin{array}{c}\text { Transfer appropriate feedback by seeing } \\
\text { ADVTs in mass media }\end{array}$ \\
\hline $\mathrm{C}_{6}$ & $\begin{array}{l}\text { Use fantasy characters in } \\
\text { promotional animations }\end{array}$ & $\mathrm{C}_{22}$ & $\begin{array}{c}\text { Effect of subtitling slogans on } \\
\text { modifying the pattern of water } \\
\text { consumption in the mass media, on } \\
\text { the audience }\end{array}$ \\
\hline $\mathrm{C}_{7}$ & $\begin{array}{l}\text { The presence of famous characters in } \\
\text { media advertising }\end{array}$ & $\mathrm{C}_{23}$ & $\begin{array}{l}\text { Creating thinking in the audience by } \\
\text { broadcasting ADVTs from mass media }\end{array}$ \\
\hline $\mathrm{C}_{8}$ & $\begin{array}{l}\text { Advertising attraction with the presence } \\
\text { of famous audience musicians }\end{array}$ & $\mathrm{C}_{24}$ & $\begin{array}{l}\text { Impressing the audience by playing a } \\
\text { real documentary to promote an } \\
\text { optimal water consumption pattern }\end{array}$ \\
\hline $\mathrm{C}_{9}$ & $\begin{array}{l}\text { The impact of athletes' } \\
\text { recommendations on the audience }\end{array}$ & $\mathrm{S}_{\mathrm{C} 1}$ & $\begin{array}{l}\text { Avoid waste of water while brushing } \\
\text { and using sanitary toilets }\end{array}$ \\
\hline $\mathrm{C}_{10}$ & $\begin{array}{l}\text { The emphasis of actors on saving water } \\
\text { consumption in media advertising }\end{array}$ & $\mathrm{S}_{\mathrm{C} 2}$ & $\begin{array}{c}\text { No necessity to wash vehicles with } \\
\text { drinkable water }\end{array}$ \\
\hline $\mathrm{C}_{11}$ & $\begin{array}{l}\text { The Impact of famous characters in } \\
\text { mass media advertising }\end{array}$ & $\mathrm{S}_{\mathrm{C} 3}$ & $\begin{array}{c}\text { Changing the valve due to the } \\
\text { valves broken }\end{array}$ \\
\hline $\mathrm{C}_{12}$ & $\begin{array}{l}\text { Better message delivery to the audience } \\
\text { with the presence of famous artists } \\
\text { in advertising }\end{array}$ & $\mathrm{S}_{\mathrm{C} 4}$ & $\begin{array}{l}\text { Not- opening the treated tap water } \\
\text { often for bathing }\end{array}$ \\
\hline $\mathrm{C}_{13}$ & $\begin{array}{l}\text { Viewing ADVTs on social networks is } \\
\text { more than other media }\end{array}$ & $\mathrm{S}_{\mathrm{C} 5}$ & $\begin{array}{l}\text { Do not use amusements and toys that } \\
\text { work with water }\end{array}$ \\
\hline $\mathrm{C}_{14}$ & $\begin{array}{l}\text { View ADVTs on friends and } \\
\text { acquaintances' social personal accounts }\end{array}$ & $\mathrm{S}_{\mathrm{C} 6}$ & $\begin{array}{l}\text { Do not use water to clean the yard and } \\
\text { roof and use alternative methods such } \\
\text { as vacuuming }\end{array}$ \\
\hline $\mathrm{C}_{15}$ & $\begin{array}{l}\text { The popularity of advertising } \\
\text { campaigns in social networks and their } \\
\text { participation in them }\end{array}$ & $\mathrm{S}_{\mathrm{C} 7}$ & $\begin{array}{l}\text { Stopping the main water split in case of } \\
\text { fracture in the pipe }\end{array}$ \\
\hline $\mathrm{C}_{16}$ & $\begin{array}{l}\text { Receive short promotional slogans } \\
\text { through social networks }\end{array}$ & $\mathrm{S}_{\mathrm{C} 8}$ & $\begin{array}{l}\text { Preferring the maintenance of plants } \\
\text { that require less water, however, is not } \\
\text { very nice }\end{array}$ \\
\hline
\end{tabular}

Table 2. The criteria numbers for each dimension.

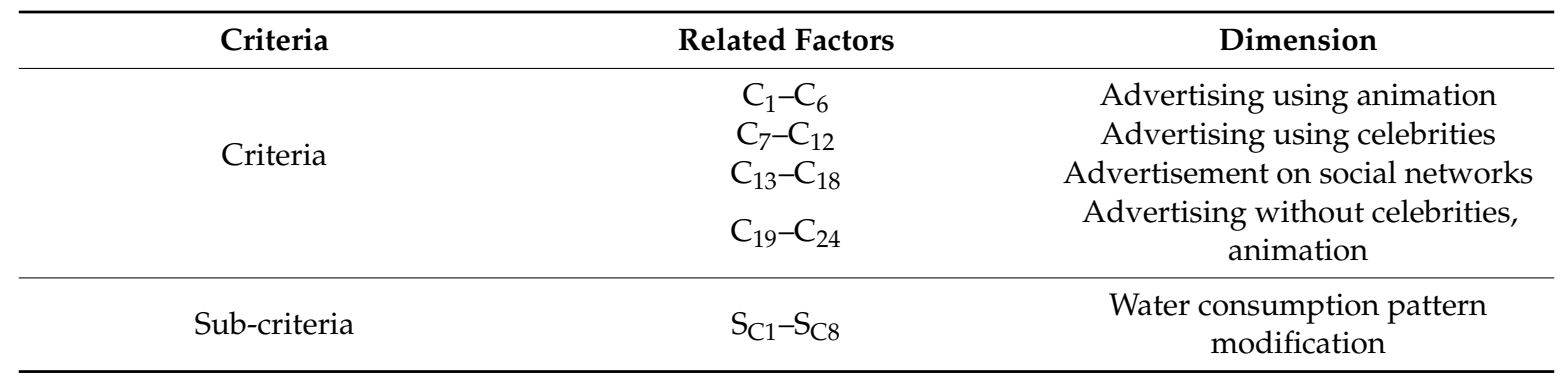

\subsection{Theories Used to Design a Questionnaire}

The highlighting method in mass media can influence the public [88,89]. Highlighting is the idea that the media provide news and topics which the public thinks about. Therefore, the television as a media, according to its educational function about modification of the water consumption pattern and appropriate training in its programs, can attract the attention of the audience to this issue.

In the theory of planting, TV is a creator and reflects the ideas, values, and beliefs that affect the institutional needs of the environment. TV also encourages people to pay attention to content that is likely to confirm earlier beliefs and ideas [90,91]. Based on the theory of social learning, people learn from observing others' actions and their consequences, and in this kind of learning, direct experience is not necessary. On the other hand, a person may not show the learned manner at the same time in his/her behavior. As occurrence of any observed behavior requires sufficient conditions and motivation, in this case, the rewards and incentives are effective in creating the background and 
motivation [92,93]. According to this theory, people can be guided by attractive symbols to save water. The social perspective theory discusses media impact on the culture and values of societies, especially children, adolescents, and young people, and how they are understood.

Based on the theory of learning, the persuasion message is persuasive when it is learned and accepted by the recipient. The method of learning consists of four stages, which are mentioned as i-iv. According to them, a compelling message is when it is convincing to reward the recipient at each of the following psychological steps: (i) The message must attract the attention of the receiver; (ii) the message's reasoning must be understood; (iii) the message recipient must learn the message arguments and accept them as the truth; (iv) we will act by these learning and beliefs that have an incentive to do so [94]. According to this theory, it is possible to avoid water loss using correct reasoning and motivations to save consumption patterns.

\subsection{Scoring Method}

A questionnaire was designed to analyze the results by the fuzzy AHP-VIKOR method to achieve the importance of alternatives and criteria to each other. In this research, 5630 questionnaires were distributed and analyzed. In each questionnaire, the responses of individuals to the impact of each criterion on the main alternatives based on the Saaty scale [95] is presented in the framework of fuzzy trapezoidal sets (see Appendix A) [96].

In addition, to increase the accuracy of the criteria evaluation in the questionnaire, the decision-making committees should determine the scores for assessing the importance of each criterion and sub-criteria. This is divided into five levels of very weak, weak, moderate, good, and very good in the form of trapezoidal fuzzy numbers (see Appendix A) [97,98].

\subsection{Alternatives and Assumptions of the Questionnaire}

The media can attract the attention of the audience due to its educational work on modifying the pattern of water consumption through appropriate training in its programs [99]. In the community for modifying the water consumption pattern, people who are more exposed to these programs are more effective than those who have not seen such plans.

In this research, we have tried to modify the pattern of water consumption among consumers by relying on the role of the mass media. In addition, a questionnaire assumes there is a relationship between each of the advertisements using animation, advertising using celebrities, advertising in social networks, and advertising without using celebrities, animation, and social networks, by modifying consumption patterns.

\subsubsection{Advertising Using Animation}

Animation is one of the alternatives, including the art of making animated and dynamic images using a computer and dynamic software that is one of the subsets of computer graphics and animation. The use of animation and visual attraction in educational and promotional messages as one of the educational methods [100] can be effective in promoting the culture of optimal water consumption in different classes of the society, especially for children and adolescents.

\subsubsection{Advertising Using Celebrities}

Celebrity advertising is a form of advertising that is used by famous and successful people in a community to send a message to the audience [52]. During recent years, using celebrities to verify and advertise the products and services on TV, radio, billboards, and magazines have been raised [101]. The dimensions and characteristics of well-known endorsers, such as apparent attractiveness, trustworthiness, and expertise on consumer attitudes toward advertising have a positive and significant impact. Today, using celebrities in advertising is due to their role as an example of mental leaders and audiences' opinions. These individuals, in the form of a reference group, can guide the tendencies and preferences of consumers towards a specific product or brand [102]. In general, 
advertisers believe the adverts advertised by celebrities are more appealing and respectful than those made by non-celebrities [52].

\subsubsection{Advertising on Social Networks}

The effectiveness of modifying the water consumption pattern in the community, regardless of the impact of using social networks, is not possible. Internet-based social networks have gained popularity among young people [103]. Although social networks are places to find new friends, simultaneously, they are places to exchange views in which young people share their ideas and opinions [104]. Moreover, the social networks can be used at many individual and social levels to identify issues and determine their solution, and establish social relationships and policy towards achieving goals [105-108].

\subsubsection{Advertising Without the use of Celebrities, Animation, and Social Networks}

The effectiveness of modifying water consumption pattern in the community, regardless of the impact of using animation, social networks, and famous personalities, also known as conceptual advertising [109], mostly depends on the level of education [110].

\subsection{Trapezoidal Fuzzy Numbers}

A trapezoidal fuzzy number is usually used to express an understanding of a function of alternatives relative to each of the criteria in a group decision [111]. In fact, a triangular fuzzy number is a special type of a trapezoidal fuzzy number, so that the two values of fuzzy sets are the same, the trapezoidal fuzzy number becomes a triangular fuzzy number. Hence, a trapezoidal fuzzy number can cope with more general conditions [111]. A trapezoidal fuzzy number is introduced in Appendix A.

\subsection{The Fuzzy AHP-VIKOR Calculation Process}

In this study, after determining the evaluation criteria and alternatives, the Fuzzy AHP-VIKOR method is proposed in this section to aggregate decision-makers' opinions, obtain the weights of the criteria, and evaluate the alternatives' ranking. The importance weight of each criterion can be obtained by fuzzy AHP based on experts' experiences or by using pairwise comparisons of criteria. Then, fuzzy VIKOR method is obtained to evaluate the alternatives ranking as a compromise solution. Fuzzy AHP and Fuzzy VIKOR are described below.

\subsubsection{Fuzzy AHP to determine weight of criteria}

In this paper, AHP method is used to aggregate individual opinions and compute the importance weight of each criterion. The procedure of the Fuzzy AHP is described in Appendix B.

2.7.2. Fuzzy VIKOR to evaluate the alternative ranking

The methodology of applying Fuzzy VIKOR for alternative selection is presented in the following subsections:

Expert opinions converted to fuzzy sets for evaluating the alternatives in relation to each criterion. Then, the decision-making opinions are evaluated to get aggregated fuzzy values $x_{i j}$ for $n$ alternatives with respect to $m$ criteria of $k$ decision-makers using Equation (1) [112].

$$
\widetilde{x}_{i j}=\frac{1}{k}\left\{\widetilde{x}_{i j}^{1} \oplus \widetilde{x}_{i j}^{2} \oplus \cdots \oplus \widetilde{x}_{i j}^{k}\right\}
$$

Where $\widetilde{x}_{i j}$ is the value of alternative $\mathrm{A}_{i}$ with respect to $C_{j}$.

Then, fuzzy decision matrix of alternatives in respect to criteria for $\mathrm{k}^{\text {th }}$ decision-makers is calculated as $\widetilde{D}=\left[\widetilde{x}_{m n}\right]$ and $\mathrm{i}=\{1,2, \ldots, \mathrm{m}\}, \mathrm{j}=\{1,2, \ldots, \mathrm{n}\}$, respectively [66]. 
In next stage, in order to have comparable criteria, the fuzzy decision matrix is normalized as follows, where B and C are the set of positive and negative criteria, respectively [71].

$$
\begin{gathered}
u_{i j}=\left(\frac{x_{i j 1}}{x_{i j 4}^{+}}, \frac{x_{i j 2}}{x_{i j 4}^{+}}, \frac{x_{i j 3}}{x_{i j 4}^{+}}, \frac{x_{i j 4}}{x_{i j 4}^{+}}\right), C_{j} \in B \\
u_{i j}=\left(\frac{x_{i j 1}}{x_{i j 1}^{-}}, \frac{x_{i j 2}}{x_{i j 1}^{-}}, \frac{x_{i j 3}}{x_{i j 1}^{-}}, \frac{x_{i j 4}}{x_{i j 1}^{-}}\right), C_{j} \in C \\
x_{i j 4}^{+}=\max _{i}\left\{x_{i j 4}\right\} C_{j} \in B \\
x_{i j 1}^{-}=\max _{i}\left\{x_{i j 1}\right\} C_{j} \in C
\end{gathered}
$$

The fuzzy decision matrix and fuzzy importance weight of each criterion is defuzzified using Equation (6) [71].

$$
\begin{aligned}
\operatorname{Defuzz}\left(f_{i j}\right)= & \frac{\int \mu(x) \cdot x d x}{\int \mu(x) \cdot d x} \\
& =\frac{\int_{i j i j}^{x_{i j 2}}\left(\frac{x-x_{i j 1}}{x_{i j 2}-x_{i j 1}}\right) \cdot x d x+\int_{x_{i j 2}}^{x_{i j 3}} x d x+\int_{x_{i j 3}}^{x_{i j 3}}\left(\frac{x_{i j 4}-x}{x_{i j 4}-x_{i j 3}}\right) \cdot x d x}{\int_{x i j 2}^{x i j}\left(\frac{x-x_{i j 1}}{x_{i j 2}-x_{i j 1}}\right) \cdot d x+\int_{x_{i j 2}}^{x_{i j 3}} d x+\int_{x_{i j 3}}^{x_{i j 4}}\left(\frac{x-x_{i j 1}}{x_{i j 2}-x_{i j 1}}\right) \cdot d x} \\
& =\frac{-x_{i j 1} x_{i j 2}+x_{i j 3} x_{i j 4}+\frac{1}{3}\left(x_{i j 4}-x_{i j 3}\right)^{2}-\frac{1}{3}\left(x_{i j 2}-x_{i j 1}\right)^{2}}{-x_{i j 1}-x_{i j 2}+x_{i j 3}+x_{i j 4}}
\end{aligned}
$$

The VIKOR method was developed based on Lp-metric as an aggregation function [113,114].

$$
L_{p i}=\left\{\sum_{j=1}^{n}\left[w_{j}\left(f_{j}^{*}-f_{i j}\right) /\left(f^{*}-f_{j}^{-}\right)\right]^{p}\right\}^{1 / p}
$$

where $L_{p i}$ is considered as an aggregating function; $f_{i j}$ is the evaluation value of criterion $\mathrm{j}$ for alternative $i ; f_{j}^{*}$ and $f_{j}^{-}$are the best and worst value of criterion $j$, respectively; $w_{j}$ is the weight of criterion $j ; m$ is the number of criteria; $n$ is the number of alternatives; $p$ denotes the weight of the maximal deviation from the ideal solution.

Therefore, the best and the worst value of defuzzified values of alternatives with respect to each criterion are determined using Equations (8) and (9).

$$
\begin{gathered}
f_{j}^{+}=\max _{j} f_{i j} \\
f_{j}^{-}=\min _{j} f_{i j}
\end{gathered}
$$

In VIKOR method The Utility $\left(S_{j}\right)$, Regret $\left(R_{j}\right)$, and VIKOR indices $\left(Q_{j}\right)$ for $\{j=1,2 \ldots m\}$ are calculated in order to rank the alternatives using Equations (10)-(12) [66].

$$
\begin{gathered}
S_{j}=\sum_{i=1}^{n} \frac{w_{j}\left(f_{i}^{+}-f_{i j}\right)}{\left(f_{i}^{+}-f_{i}^{-}\right)} \\
R_{j}=\max _{i}\left(\frac{w_{j}\left(f_{i}^{+}-f_{i j}\right)}{\left(f_{i}^{+}-f_{i}^{-}\right)}\right) \\
Q_{j}=\frac{w_{j}\left(S_{i}-S_{*}\right)}{\left(S^{-}-S *\right)}+\frac{v_{j}\left(R_{i}-R^{*}\right)}{\left(R^{-}-R^{*}\right)}
\end{gathered}
$$


Where $\mathrm{w}_{\mathrm{j}}$ is the importance weight of $\mathrm{j}$ criterion, and $S^{*}=\min S_{i}, S^{-}=\max S_{i}, R^{*}=\min R_{i}$, and $R^{-}=\max R_{i} . v$ is the weight for decision making alternative of "the majority of the criteria" [66], and $1-v$ is the weight of individual regret $v \in[1,0]$, usually $v=0.5$ [77].

In the final step, the ranking of the alternatives is sorted by using each $S_{j}, R_{j}$, and $Q_{i}$ in ascending order. The alternative with the smallest VIKOR value is specified to be the best solution. The highest-ranked alternative $\left(\mathrm{A}^{1}\right)$ based on VIKOR values in ascending order is the compromise solution if the following two conditions are satisfied.

$\mathrm{C}_{1}$. Acceptable advantage:

$$
\mathrm{Q}\left(\mathrm{A}^{2}\right)-\mathrm{Q}\left(\mathrm{A}^{1}\right) \geq \frac{1}{(\mathrm{~m}-1)}
$$

where $\mathrm{A}^{2}$ is the second preference in the alternative ranking, and $\mathrm{m}$ is the number of alternatives, which in this study is 4 .

$\mathrm{C}_{2}$. Acceptable stability in decision-making:

Alternative $A^{1}$ also must be ranked best through $S_{i}$ and $R_{i}$.

If one of the conditions is not satisfied, a set of compromise solutions is proposed, including:

- Alternatives $\mathrm{A}^{1}$ and $\mathrm{A}^{2}$ if only the $\mathrm{C}_{2}$ condition is not satisfied.

- Alternatives $\mathrm{A}^{1}, \mathrm{~A}^{2} \ldots \mathrm{A}^{\mathrm{m}}$ if the $\mathrm{C}_{1}$ condition is not satisfied; then, $\mathrm{A}^{\mathrm{m}}$ is determined using equation $Q\left(A^{m}\right)-Q\left(A^{1}\right)<\frac{1}{m-1}$ for the maximum $m$.

The framework of the proposed method is shown in Figure 2.

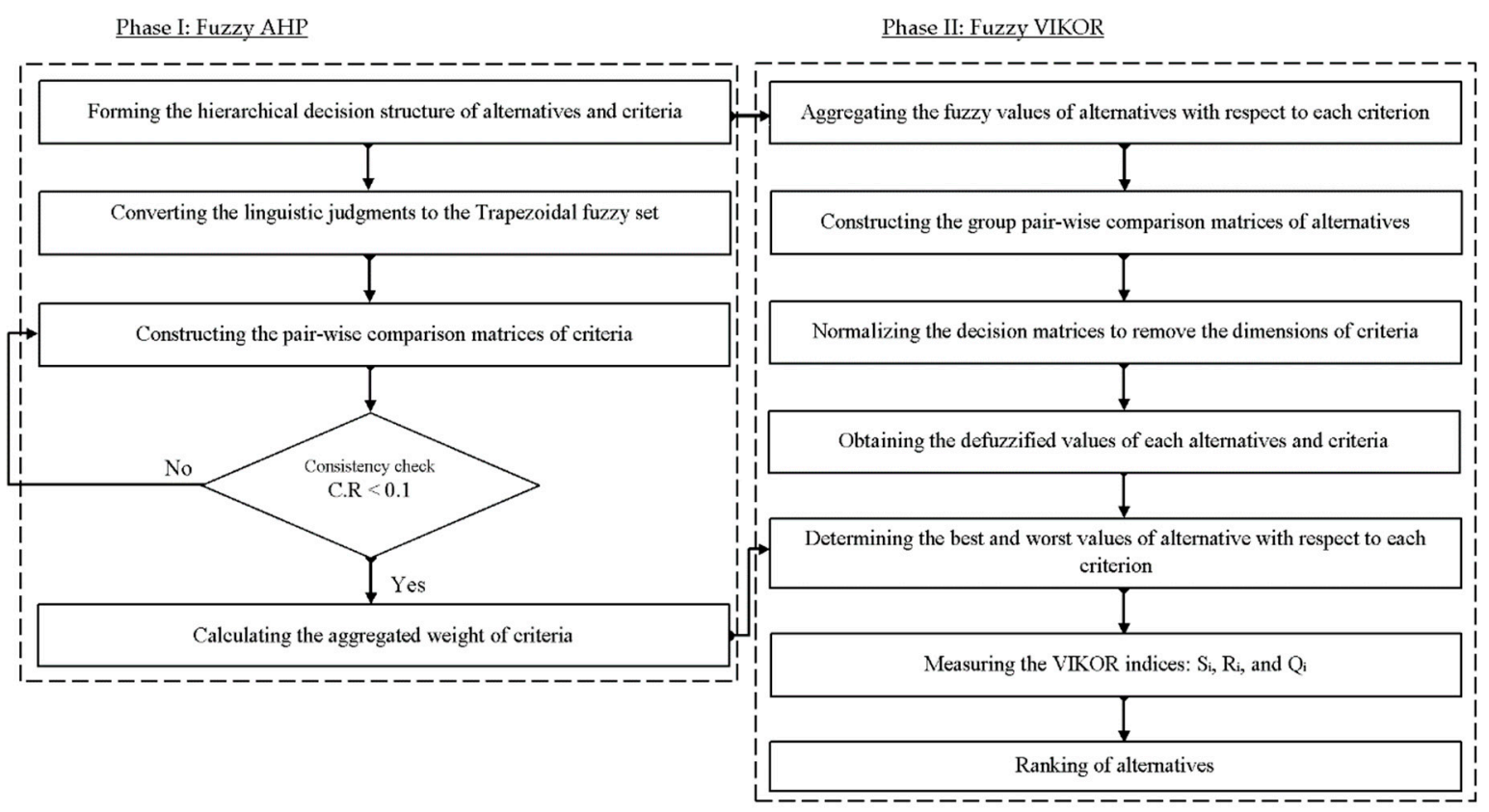

Figure 2. Framework of the proposed evaluation approach.

\subsection{Fuzzy Evaluation Technique}

Based on the trapezoidal fuzzy number evaluation and the fuzzy weight vector, the fuzzy evaluation of the criteria values is calculated as follows [98]:

(a) Formation of fuzzy evaluation matrix

The evaluation of the relative values of criterion $\mathrm{j}\left(\widetilde{f_{j}}\right)$ is based on the choices of decision-makers from Equation (14):

$$
\widetilde{f_{j}}=\frac{1}{k}\left(\widetilde{f_{j}^{1}}+\widetilde{f_{j}^{2}}+\ldots \widetilde{f}_{j}^{k}\right)
$$


In which $\widetilde{f_{j}^{k}}=(l, m, n, s)$ is a fuzzy number that implies the evaluation of criterion $\mathrm{j}$ based on the decision maker $\mathrm{K}\left(\mathrm{D}_{\mathrm{K}}\right) 1 \leq j \leq n$. Then the fuzzy evaluation matrix can be obtained from Equation (15):

$$
\widetilde{F}=\left[\begin{array}{llll}
\tilde{f}_{1} & \widetilde{f}_{2} & \ldots & \widetilde{f}_{n}
\end{array}\right]
$$

(b) Calculate the fuzzy evaluation vector

Based on the wj weights and the fuzzy evaluation matrix $\widetilde{F}$, the fuzzy evaluation vector $\widetilde{Z}$ is obtained as Equation (15):

$$
\begin{gathered}
\widetilde{Z}=\left(\left(\widetilde{w}_{1} \otimes \widetilde{f}_{1}\right) \oplus\left(\widetilde{w}_{2} \otimes \widetilde{f}_{2}\right) \oplus\left(\widetilde{w}_{3} \otimes \widetilde{f}_{3}\right) \oplus \cdots \oplus\left(\widetilde{w}_{j} \otimes \widetilde{f}_{j}\right)\right) \phi\left(\widetilde{w}_{1}\right. \\
\left.\oplus \widetilde{w}_{2} \oplus \widetilde{w}_{3} \oplus \cdots \oplus \widetilde{w}_{j}\right)
\end{gathered}
$$

\section{Applying the Proposed Method}

The importance weight of quantitative and qualitative criteria and identifying the most effective alternative for modifying consumption pattern are calculated using the AHP-VIKOR model based on the fuzzy evaluation of values in the trapezoidal fuzzy number framework. The main questions of this study include examining the research hypotheses "there is an association between assumptions and modifying the pattern of consumption", the role of each criterion in modifying the pattern of consumption, the nature of the advertising types in changing the behavior of consumers, and finding the most effective advertising method, as well, which tried to be answered.

\section{Application of the Proposed Method}

First, all the criteria and alternatives are taken into account by the hierarchical decision tree (see Figure 3).

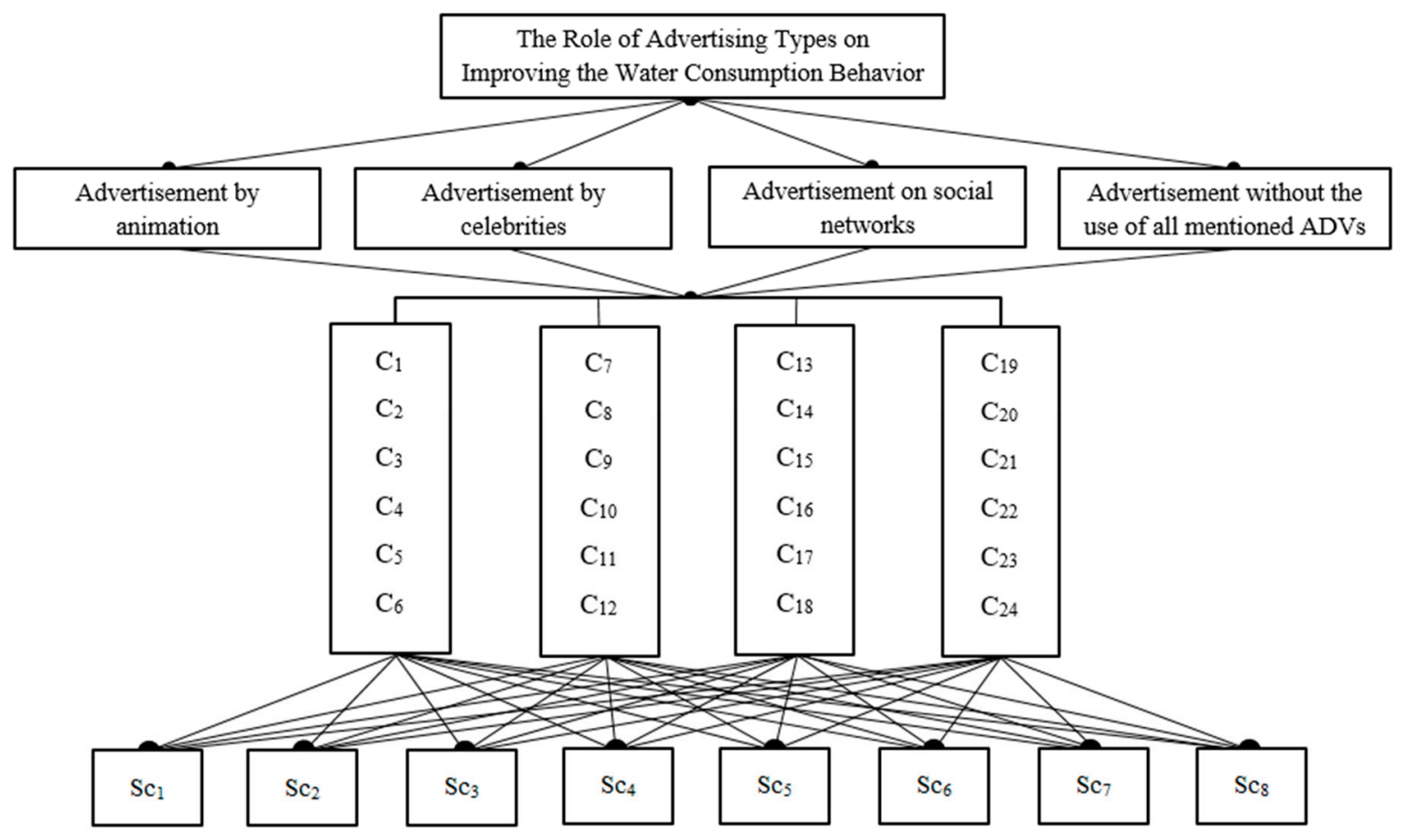

Figure 3. The hierarchical decision tree.

In the next step, the responses of the questioners are converted into fuzzy comparisons based on fuzzy scales to compare their relative importance concerning other criteria, and then the linguistic 
variables to are used compare the relative importance of the criteria. These linguistic variables are shown in Table 3.

Table 3. Linguistic variables based on nine-point scale on fuzzy trapezoidal numbers [96].

\begin{tabular}{ccc}
\hline Linguistic Variables & Trapezoidal Fuzzy Numbers & Relative Importance Scale \\
\hline Equal importance & $(1,1,1,1)$ & 1 \\
Weakly important & $(2,5 / 2,7 / 2,4)$ & 3 \\
important & $(4,9 / 2,11 / 2,6)$ & 5 \\
Strongly important & $(6,13 / 2,15 / 2,8)$ & 7 \\
Absolutely important & $(8,17 / 2,9,9)$ & 9 \\
- & $(x-1, x-1 / 2, x+1 / 2, x+1)$ & ) $2,4,6,8$ (intermediate scales \\
\hline
\end{tabular}

Then, to assess the fuzzy set values for each criterion and alternatives with respect to criteria, the linguistic variables can be expressed by trapezoidal fuzzy numbers, as shown in Table 4 .

Table 4. Linguistic statements and fuzzy scales for criteria and alternatives [97].

\begin{tabular}{cccc}
\hline $\begin{array}{c}\text { Fuzzy Scale for } \\
\text { Alternatives }\end{array}$ & $\begin{array}{c}\text { Linguistic Statements } \\
\text { for Alternatives }\end{array}$ & Fuzzy Scale for Criteria & $\begin{array}{c}\text { Linguistic Statements } \\
\text { for Criteria }\end{array}$ \\
\hline$(0,0,0.1,0.2)$ & Very Low & $(0,1,2,3)$ & Very Weak \\
$(0.1,0.25,0.25,0.4)$ & Low & $(1,2,3,4)$ & Weak \\
$(0.3,0.5,0.5,0.7)$ & Moderate & $(3,4,5,6)$ & Moderate \\
$(0.6,0.75,0.75,0.9)$ & High & $(5,6,7,8)$ & Good \\
$(0.8,0.9,1,1)$ & Very High & $(7,8,9,10)$ & Very Good \\
\hline
\end{tabular}

The value of the C.I is calculated for the matrices, where their numbers are randomly chosen and have been named as the value of R.I. The amount of R.I of matrices is shown in Table 5.

Table 5. The value of the random index, (R.I) of matrices.

\begin{tabular}{cccccccccc}
\hline $\mathbf{n}$ & $\mathbf{1}$ & $\mathbf{2}$ & $\mathbf{3}$ & $\mathbf{4}$ & $\mathbf{5}$ & $\mathbf{6}$ & $\mathbf{7}$ & $\mathbf{8}$ & $\mathbf{9}$ \\
\hline R.I & 0 & 0 & 0.58 & 0.9 & 1.12 & 1.24 & 1.32 & 1.41 & 1.45 \\
\hline
\end{tabular}

If the Consistency rate is 0.1 or less, it indicates the consistency of the comparisons and the validity of the respondents is confirmed.

In the next stage, according to the trapezoidal fuzzy numbers that indicate each of the linguistic variables and their mathematical operations (Equations A1-A6), the pairwise comparison matrix of the alternatives and criteria related to each alternative are presented in Tables 6-10 and Sub-criteria in Table 11 by using Equations (A8-A10).

Table 6. Pairwise comparison matrix of alternatives $\left(A_{i}\right)$.

\begin{tabular}{ccccccccc}
\hline \multirow{2}{*}{$\mathbf{A}_{\mathbf{i}}$} & \multicolumn{4}{c}{ Fuzzy AHP } & \multicolumn{4}{c}{ Proposed Method } \\
\cline { 2 - 9 } & $\mathbf{A}$ & $\mathbf{B}$ & $\mathbf{C}$ & $\mathbf{D}$ & $\mathbf{A}$ & $\mathbf{B}$ & $\mathbf{C}$ & $\mathbf{D}$ \\
\hline $\mathrm{A}$ & 1 & 2 & 3 & 5 & $1,1,1,1$ & $1,1,3 / 2,2$ & $2,5 / 2,7 / 2,4$ & $4,9 / 2,11 / 2,6$ \\
\hline $\mathrm{B}$ & 0.5 & 1 & 3 & 5 & $1 / 2,2 / 3,1,1$ & $1,1,1,1$ & $2,5 / 2,7 / 2,4$ & $4,9 / 2,11 / 2,6$ \\
\hline $\mathrm{C}$ & 0.333 & 0.333 & 1 & 3 & $1 / 4,2 / 7,2 / 5,1 / 2$ & $1 / 4,2 / 7,2 / 5,1 / 2$ & $1,1,1,1$ & $2,5 / 2,7 / 2,4$ \\
\hline $\mathrm{D}$ & 0.2 & 0.2 & 0.33 & 1 & $1 / 6,2 / 11,2 / 9,1 / 4$ & $1 / 6,2 / 11,2 / 9,1 / 4$ & $1 / 4,2 / 7,2 / 5,1 / 2$ & $1,1,1,1$ \\
\hline
\end{tabular}


Table 7. The paired comparison matrix of $C_{1}-C_{6}$ in relation to alternative $A$.

\begin{tabular}{ccccccc}
\hline \multirow{2}{*}{ Criteria } & \multicolumn{5}{c}{ Criteria } \\
\cline { 2 - 6 } & $\mathrm{C}_{\mathbf{1}}$ & $\mathrm{C}_{\mathbf{2}}$ & $\mathrm{C}_{\mathbf{3}}$ & $\mathrm{C}_{\mathbf{4}}$ & $\mathrm{C}_{\mathbf{5}}$ \\
\hline $\mathrm{C}_{1}$ & $1.00,1.00,1.00,1.00$ & $4.00,4.50,5.50,6.00$ & $1.00,1.00,1.00,1.00$ & $4.00,4.50,5.50,6.00$ & $6.00,6.50,7.50,8.00$ & $2.00,2.50,3.50,4.00$ \\
\hline $\mathrm{C}_{2}$ & $0.16,0.18,0.22,0.25$ & $1.00,1.00,1.00,1.00$ & $2.00,2.50,3.50,4.00$ & $2.00,2.50,3.50,4.00$ & $4.00,4.50,5.50,6.00$ & $2.00,2.50,3.50,4.00$ \\
\hline$C_{3}$ & $1.00,1.00,1.00,1.00$ & $0.25,0.29,0.40,0.50$ & $1.00,1.00,1.00,1.00$ & $4.00,4.50,5.50,6.00$ & $6.00,6.50,7.50,8.00$ & $2.00,2.50,3.50,4.00$ \\
\hline$C_{4}$ & $0.16,0.18,0.22,0.25$ & $0.17,0.18,0.22,0.25$ & $0.17,0.18,0.22,0.25$ & $1.00,1.00,1.00,1.00$ & $4.00,4.50,5.50,6.00$ & $2.00,2.50,3.50,4.00$ \\
\hline$C_{5}$ & $0.12,0.13,0.15,0.16$ & $0.17,0.18,0.22,0.25$ & $0.12,0.13,0.15,0.16$ & $0.17,0.18,0.22,0.25$ & $1.00,1.00,1.00,1.00$ & $2.00,2.50,3.50,4.00$ \\
\hline$C_{6}$ & $0.25,0.28,0.40,0.50$ & $0.25,0.29,0.40,0.50$ & $0.25,0.28,0.40,0.50$ & $0.25,0.29,0.40,0.50$ & $0.25,0.28,0.40,0.50$ & $1.00,1.00,1.00,1.00$ \\
\hline$C R=0.0305$ & & & & & &
\end{tabular}

Table 8. The paired comparison matrix of $\mathrm{C} 7-\mathrm{C} 12$ in relation to alternative $\mathrm{B}$.

\begin{tabular}{|c|c|c|c|c|c|c|}
\hline \multirow{2}{*}{ Criteria } & \multicolumn{6}{|c|}{ Criteria } \\
\hline & $\mathrm{C}_{7}$ & $\mathrm{C}_{8}$ & $\mathrm{C}_{9}$ & $\mathrm{C}_{10}$ & $\mathrm{C}_{11}$ & $\mathrm{C}_{12}$ \\
\hline $\mathrm{C}_{7}$ & $1.00,1.00,1.00,1.00$ & $4.00,4.50,5.50,6.00$ & $6.00,6.50,7.50,8.00$ & $6.00,6.50,7.50,8.00$ & $4.00,4.50,5.50,6.00$ & $4.00,4.50,5.50,6.00$ \\
\hline $\mathrm{C}_{9}$ & $0.12,0.13,0.15,0.17$ & $1.00,1.00,1.00,1.00$ & $1.00,1.00,1.00,1.00$ & $1.00,1.00,1.00,1.00$ & $1.00,1.00,1.00,1.00$ & $1.00,1.00,1.00,1.00$ \\
\hline $\mathrm{C}_{10}$ & $0.12,0.13,0.15,0.16$ & $1.00,1.00,1.00,1.00$ & $1.00,1.00,1.00,1.00$ & $1.00,1.00,1.00,1.00$ & $1.00,1.00,1.00,1.00$ & $1.00,1.00,1.00,1.00$ \\
\hline $\mathrm{C}_{11}$ & $0.17,0.18,0.22,0.25$ & $1.00,1.00,1.00,1.00$ & $1.00,1.00,1.00,1.00$ & $1.00,1.00,1.00,1.00$ & $1.00,1.00,1.00,1.00$ & $1.00,1.00,1.00,1.00$ \\
\hline $\mathrm{C}_{12}$ & $0.16,0.18,0.22,0.25$ & $1.00,1.00,1.00,1.00$ & $1.00,1.00,1.00,1.00$ & $1.00,1.00,1.00,1.00$ & $1.00,1.00,1.00,1.00$ & $1.00,1.00,1.00,1.00$ \\
\hline$C R=0.0543$ & & & & & & \\
\hline
\end{tabular}


Table 9. The paired comparison matrix of $C_{13}-C_{18}$ in relation to alternative $C$.

\begin{tabular}{|c|c|c|c|c|c|c|}
\hline \multirow{2}{*}{ Criteria } & \multicolumn{6}{|c|}{ Criteria } \\
\hline & $\mathrm{C}_{13}$ & $\mathrm{C}_{14}$ & $\mathrm{C}_{15}$ & $\mathrm{C}_{16}$ & $\mathrm{C}_{17}$ & $\mathrm{C}_{18}$ \\
\hline $\mathrm{C}_{13}$ & $1.00,1.00,1.00,1.00$ & $1.00,1.00,1.00,1.00$ & $1.00,1.00,1.00,1.00$ & $2.00,2.50,3.50,4.00$ & $2.00,2.50,3.50,4.00$ & $1.00,1.00,1.00,1.00$ \\
\hline $\mathrm{C}_{15}$ & $1.00,1.00,1.00,1.00$ & $1.00,1.00,1.00,1.00$ & $1.00,1.00,1.00,1.00$ & $2.00,2.50,3.50,4.00$ & $2.00,2.50,3.50,4.00$ & $1.00,1.00,1.00,1.00$ \\
\hline $\mathrm{C}_{16}$ & $0.25,0.28,0.40,0.50$ & $0.25,0.29,0.40,0.50$ & $0.25,0.29,0.40,0.50$ & $1.00,1.00,1.00,1.00$ & $4.00,4.50,5.50,6.00$ & $6.00,6.50,7.50,8.00$ \\
\hline $\mathrm{C}_{17}$ & $0.25,0.29,0.40,0.50$ & $0.25,0.29,0.40,0.50$ & $0.25,0.29,0.40,0.50$ & $0.17,0.18,0.22,0.25$ & $1.00,1.00,1.00,1.00$ & $8.00,8.50,9.00,9.00$ \\
\hline $\mathrm{C}_{18}$ & $1.00,1.00,1.00,1.00$ & $1.00,1.00,1.00,1.00$ & $1.00,1.00,1.00,1.00$ & $0.12,0.13,0.15,0.16$ & $0.11,0.11,0.12,0.12$ & $1.00,1.00,1.00,1.00$ \\
\hline$C R=0.0815$ & & & & & & \\
\hline
\end{tabular}

Table 10. The paired comparison matrix of $C_{19}-C_{24}$ in relation to alternative $D$.

\begin{tabular}{|c|c|c|c|c|c|c|}
\hline \multirow{2}{*}{ Criteria } & \multicolumn{6}{|c|}{ Criteria } \\
\hline & $\mathrm{C}_{19}$ & $\mathrm{C}_{20}$ & $\mathrm{C}_{21}$ & $\mathrm{C}_{22}$ & $\mathrm{C}_{23}$ & $\mathrm{C}_{24}$ \\
\hline $\mathrm{C}_{19}$ & $1.00,1.00,1.00,1.00$ & $6.00,6.50,7.50,8.00$ & $4.00,4.50,5.50,6.00$ & $4.00,4.50,5.50,6.00$ & $4.00,4.50,5.50,6.00$ & $2.00,2.50,3.50,4.00$ \\
\hline $\mathrm{C}_{20}$ & $0.12,0.13,0.15,0.17$ & $1.00,1.00,1.00,1.00$ & $2.00,2.50,3.50,4.00$ & $2.00,2.50,3.50,4.00$ & $2.00,2.50,3.50,4.00$ & $2.00,2.50,3.50,4.00$ \\
\hline $\mathrm{C}_{21}$ & $0.17,0.18,0.22,0.25$ & $0.25,0.29,0.40,0.50$ & $1.00,1.00,1.00,1.00$ & $1.00,1.00,1.00,1.00$ & $4.00,4.50,5.50,6.00$ & $2.00,2.50,3.50,4.00$ \\
\hline $\mathrm{C}_{22}$ & $0.17,0.18,0.22,0.25$ & $0.25,0.29,0.40,0.50$ & $1.00,1.00,1.00,1.00$ & $1.00,1.00,1.00,1.00$ & $1.00,1.00,1.00,1.00$ & $2.00,2.50,3.50,4.00$ \\
\hline $\mathrm{C}_{23}$ & $0.17,0.18,0.22,0.25$ & $0.25,0.29,0.40,0.50$ & $0.17,0.18,0.22,0.25$ & $1.00,1.00,1.00,1.00$ & $1.00,1.00,1.00,1.00$ & $2.00,2.50,3.50,4.00$ \\
\hline $\mathrm{C}_{24}$ & $0.25,0.29,0.40,0.50$ & $0.25,0.29,0.40,0.50$ & $0.25,0.29,0.40,0.50$ & $0.25,0.29,0.40,0.50$ & $0.25,0.29,0.40,0.50$ & $1.00,1.00,1.00,1.00$ \\
\hline
\end{tabular}


Table 11. The pairwise comparison matrix of sub-criteria $S_{C 1}-S_{C 8}$ in relation to all alternatives.

\begin{tabular}{|c|c|c|c|c|c|c|c|c|}
\hline \multirow{2}{*}{ Sub-Criteria } & \multicolumn{8}{|c|}{ Sub-Criteria } \\
\hline & $\mathrm{S}_{\mathrm{C} 1}$ & $\mathrm{~S}_{\mathrm{C} 2}$ & $\mathrm{~S}_{\mathrm{C} 3}$ & $\mathrm{~S}_{\mathrm{C} 4}$ & $\mathrm{~S}_{\mathrm{C} 5}$ & $\mathrm{~S}_{\mathrm{C} 6}$ & $\mathrm{~S}_{\mathrm{C} 7}$ & $\mathrm{~S}_{\mathrm{C} 8}$ \\
\hline $\mathrm{S}_{\mathrm{C} 1}$ & $1.00,1.00,1.00,1.00$ & $1.00,1.00,1.00,1.00$ & $2.00,2.50,3.50,4.00$ & $6.00,6.50,7.50,8.00$ & $8.00,8.50,9.00,9.00$ & $6.00,6.50,7.50,8.00$ & $2.00,2.50,3.50,4.00$ & $1.00,1.00,1.00,1.00$ \\
\hline $\mathrm{S}_{\mathrm{C} 2}$ & $1.00,1.00,1.00,1.00$ & $1.00,1.00,1.00,1.00$ & $2.00,2.50,3.50,4.00$ & $6.00,6.50,7.50,8.00$ & $8.00,8.50,9.00,9.00$ & $6.00,6.50,7.50,8.00$ & $6.00,6.50,7.50,8.00$ & $1.00,1.00,1.00,1.00$ \\
\hline $\mathrm{S}_{\mathrm{C} 3}$ & $0.25,0.29,0.40,0.50$ & $0.25,0.28,0.40,0.50$ & $1.00,1.00,1.00,1.00$ & $8.00,8.50,9.00,9.00$ & $8.00,8.50,9.00,9.00$ & $8.00,8.50,9.00,9.00$ & $8.00,8.50,9.00,9.00$ & $6.00,6.50,7.50,8.00$ \\
\hline $\mathrm{S}_{\mathrm{C} 4}$ & $0.12,0.13,0.15,0.17$ & $0.12,0.13,0.15,0.17$ & $0.11,0.11,0.118,0.12$ & $1.00,1.00,1.00,1.00$ & $4.00,4.50,5.50,6.00$ & $1.00,1.00,1.00,1.00$ & $6.00,6.50,7.50,8.00$ & $6.00,6.50,7.50,8.00$ \\
\hline $\mathrm{S}_{\mathrm{C} 5}$ & $0.11,0.11,0.12,0.12$ & $0.11,0.11,0.118,0.12$ & $0.11,0.11,0.118,0.12$ & $0.17,0.18,0.22,0.25$ & $1.00,1.00,1.00,1.00$ & $2.00,2.50,3.50,4.00$ & $2.00,2.50,3.50,4.00$ & $2.00,2.50,3.50,4.00$ \\
\hline $\mathrm{S}_{\mathrm{C} 6}$ & $0.12,0.13,0.15,0.17$ & $0.12,0.13,0.15,0.17$ & $0.11,0.11,0.12,0.12$ & $1.00,1.00,1.00,1.00$ & $0.25,0.27,0.40,0.50$ & $1.00,1.00,1.00,1.00$ & $4.00,4.50,5.50,6.00$ & $2.00,2.50,3.50,4.00$ \\
\hline $\mathrm{S}_{\mathrm{C} 7}$ & $0.25,0.29,0.40,0.50$ & $0.12,0.13,0.15,0.17$ & $0.11,0.11,0.118,0.12$ & $0.12,0.13,0.15,0.17$ & $0.25,0.29,0.400,0.50$ & $0.17,0.18,0.22,0.25$ & $1.00,1.00,1.00,1.00$ & $2.00,2.50,3.50,4.00$ \\
\hline $\mathrm{S}_{\mathrm{C} 8}$ & $1.00,1.00,1.00,1.00$ & $1.00,1.00,1.00,1.00$ & $0.12,0.13,0.15,0.17$ & $0.12,0.13,0.15,0.17$ & $0.25,0.29,0.40,0.50$ & $0.25,0.29,0.40,0.50$ & $0.25,0.29,0.40,0.50$ & $1.00,1.00,1.00,1.00$ \\
\hline
\end{tabular}


Then, based on the decision committee opinions, the initial evaluation data for the sub-criteria are summarized in Table 12.

Table 12. Summary of the initial data evaluation for criteria and sub-criteria.

\begin{tabular}{|c|c|c|c|c|c|}
\hline Criteria & Very Weak & Weak & Moderate & Good & Very Good \\
\hline $\mathrm{C}_{1}$ & $260 *$ & 835 & 1169 & 2616 & 979 \\
\hline $\mathrm{C}_{2}$ & 289 & 851 & 1143 & 2670 & 901 \\
\hline $\mathrm{C}_{3}$ & 325 & 779 & 1089 & 2690 & 970 \\
\hline $\mathrm{C}_{4}$ & 384 & 826 & 1075 & 2656 & 913 \\
\hline $\mathrm{C}_{5}$ & 376 & 860 & 1196 & 2540 & 879 \\
\hline $\mathrm{C}_{6}$ & 366 & 739 & 1106 & 2631 & 1008 \\
\hline $\mathrm{C}_{7}$ & 313 & 801 & 1179 & 2554 & 1004 \\
\hline $\mathrm{C}_{8}$ & 395 & 860 & 1155 & 2516 & 924 \\
\hline $\mathrm{C}_{9}$ & 371 & 887 & 1262 & 2421 & 910 \\
\hline $\mathrm{C}_{10}$ & 358 & 900 & 1338 & 2316 & 938 \\
\hline $\mathrm{C}_{11}$ & 399 & 828 & 1305 & 2377 & 941 \\
\hline $\mathrm{C}_{12}$ & 345 & 824 & 1181 & 2565 & 935 \\
\hline $\mathrm{C}_{13}$ & 403 & 869 & 1281 & 2422 & 875 \\
\hline $\mathrm{C}_{14}$ & 507 & 887 & 1216 & 2397 & 843 \\
\hline $\mathrm{C}_{15}$ & 357 & 902 & 1307 & 2402 & 882 \\
\hline $\mathrm{C}_{16}$ & 306 & 869 & 1239 & 2464 & 972 \\
\hline $\mathrm{C}_{17}$ & 334 & 876 & 1263 & 2419 & 958 \\
\hline $\mathrm{C}_{18}$ & 471 & 940 & 1143 & 2477 & 821 \\
\hline $\mathrm{C}_{19}$ & 315 & 738 & 1344 & 2451 & 1003 \\
\hline $\mathrm{C}_{20}$ & 386 & 847 & 1109 & 2588 & 921 \\
\hline $\mathrm{C}_{21}$ & 265 & 868 & 987 & 2769 & 962 \\
\hline $\mathrm{C}_{22}$ & 368 & 760 & 1231 & 2536 & 956 \\
\hline $\mathrm{C}_{23}$ & 313 & 803 & 1154 & 2597 & 984 \\
\hline $\mathrm{C}_{24}$ & 380 & 749 & 1036 & 2647 & 1039 \\
\hline \multicolumn{6}{|c|}{ Sub-Criteria } \\
\hline $\mathrm{S}_{\mathrm{C} 1}$ & 365 & 728 & 1074 & 2392 & 1292 \\
\hline $\mathrm{S}_{\mathrm{C} 2}$ & 358 & 779 & 1126 & 2318 & 1269 \\
\hline $\mathrm{S}_{\mathrm{C} 3}$ & 305 & 705 & 1047 & 2469 & 1325 \\
\hline $\mathrm{S}_{\mathrm{C} 4}$ & 439 & 961 & 1047 & 2379 & 1027 \\
\hline $\mathrm{S}_{\mathrm{C} 5}$ & 482 & 864 & 1235 & 2320 & 952 \\
\hline $\mathrm{S}_{\mathrm{C} 6}$ & 333 & 806 & 1165 & 2469 & 1080 \\
\hline $\mathrm{S}_{\mathrm{C} 7}$ & 356 & 817 & 1047 & 2507 & 1126 \\
\hline $\mathrm{S}_{\mathrm{C} 8}$ & 308 & 789 & 1102 & 2432 & 1222 \\
\hline
\end{tabular}

* The number of decision makers who consider the same value for the sub-criteria.

Before calculating the weights, the consistency of pairwise comparison matrices is examined using the Equations (A11-A13). All comparison matrices are compatible, due to the computational limitations, the consistency checking processes are not shown in the paper, and only the final results are shown in Tables 6-11. Based on the results of the pairwise comparison matrices obtained from Tables 6-11, the weight of the criteria and alternatives can be calculated using Equations (A15 and A16). The results of the calculations are shown in Tables 13 and 14. 
Table 13. The weight of criteria and sub-criteria.

\begin{tabular}{|c|c|c|c|c|}
\hline \multirow{2}{*}{ Alternative } & \multirow{2}{*}{ Criteria } & \multicolumn{2}{|c|}{ Proposed Method } & \multirow{2}{*}{$\begin{array}{c}\text { Fuzzy AHP } \\
\text { Weight }\end{array}$} \\
\hline & & Fuzzy Weight Vector & Defuzzy Weight & \\
\hline \multirow{6}{*}{$\mathrm{A}$} & $\mathrm{C}_{1}$ & $0.1590,0.1630,0.1710,0.1753$ & 0.167 & 0.163 \\
\hline & $\mathrm{C}_{2}$ & $0.1587,0.1627,0.1708,0.1750$ & 0.165 & 0.155 \\
\hline & $\mathrm{C}_{3}$ & $0.1590,0.1630,0.1710,0.1752$ & 0.169 & 0.167 \\
\hline & $\mathrm{C}_{4}$ & $0.1585,0.1625,0.1705,0.1747$ & 0.166 & 0.173 \\
\hline & $\mathrm{C}_{5}$ & $0.1582,0.1621,0.1702,0.1745$ & 0.159 & 0.153 \\
\hline & $\mathrm{C}_{6}$ & $0.1590,0.1630,0.1709,0.1751$ & 0.164 & 0.161 \\
\hline \multirow{6}{*}{ B } & $\mathrm{C}_{7}$ & $0.1593,0.1633,0.1713,0.1756$ & 0.167 & 0.161 \\
\hline & $\mathrm{C}_{8}$ & $0.1586,0.1626,0.1707,0.1750$ & 0.166 & 0.145 \\
\hline & $\mathrm{C}_{9}$ & $0.1584,0.1624,0.1705,0.1748$ & 0.165 & 0.166 \\
\hline & $\mathrm{C}_{10}$ & $0.1583,0.1624,0.1705,0.1748$ & 0.167 & 0.151 \\
\hline & $\mathrm{C}_{11}$ & $0.1585,0.1625,0.1705,0.1748$ & 0.166 & 0.151 \\
\hline & $\mathrm{C}_{12}$ & $0.1589,0.1629,0.1710,0.1753$ & 0.168 & 0.160 \\
\hline \multirow{6}{*}{$\mathrm{C}$} & $\mathrm{C}_{13}$ & $0.1585,0.1626,0.1708,0.1751$ & 0.167 & 0.157 \\
\hline & $\mathrm{C}_{14}$ & $0.1581,0.1621,0.1702,0.1746$ & 0.165 & 0.165 \\
\hline & $\mathrm{C}_{15}$ & $0.1586,0.1626,0.1709,0.1752$ & 0.168 & 0.165 \\
\hline & $\mathrm{C}_{16}$ & $0.1592,0.1633,0.1714,0.1758$ & 0.167 & 0.156 \\
\hline & $\mathrm{C}_{17}$ & $0.1590,0.1630,0.1712,0.1755$ & 0.172 & 0.165 \\
\hline & $\mathrm{C}_{18}$ & $0.1581,0.1622,0.1703,0.1747$ & 0.166 & 0.162 \\
\hline \multirow{6}{*}{$\mathrm{D}$} & $\mathrm{C}_{19}$ & $0.1588,0.1627,0.1707,0.1749$ & 0.166 & 0.162 \\
\hline & $\mathrm{C}_{20}$ & $0.1584,0.1623,0.1703,0.1745$ & 0.166 & 0.154 \\
\hline & $\mathrm{C}_{21}$ & $0.1591,0.1631,0.1710,0.1753$ & 0.167 & 0.162 \\
\hline & $\mathrm{C}_{22}$ & $0.1586,0.1625,0.1705,0.1747$ & 0.166 & 0.169 \\
\hline & $\mathrm{C}_{23}$ & $0.1589,0.1628,0.1708,0.1750$ & 0.167 & 0.157 \\
\hline & $\mathrm{C}_{24}$ & $0.1591,0.1630,0.1709,0.1750$ & 0.167 & 0.165 \\
\hline \multirow{8}{*}{ Sub-criteria } & $\mathrm{S}_{\mathrm{C} 1}$ & $0.1120,0.1141,0.1181,0.1201$ & 0.139 & 0.141 \\
\hline & $\mathrm{S}_{\mathrm{C} 2}$ & $0.118,0.1139,0.1180,0.1199$ & 0.139 & 0.132 \\
\hline & $\mathrm{S}_{\mathrm{C} 3}$ & $0.0943,0.0952,0.0972,0.0982$ & 0.140 & 0.126 \\
\hline & $\mathrm{S}_{\mathrm{C} 4}$ & $0.0938,0.0948,0.0968,0.0979$ & 0.125 & 0.122 \\
\hline & $\mathrm{S}_{\mathrm{C} 5}$ & $0.0938,0.0947,0.0968,0.0978$ & 0.119 & 0.098 \\
\hline & $\mathrm{S}_{\mathrm{C} 6}$ & $0.0940,0.0950,0.0970,0.0981$ & 0.113 & 0.103 \\
\hline & $\mathrm{S}_{\mathrm{C} 7}$ & $0.0941,0.0950,0.0970,0.0981$ & 0.120 & 0.104 \\
\hline & $\mathrm{S}_{\mathrm{C} 8}$ & $0.0942,0.0951,0.0971,0.0982$ & 0.106 & 0.097 \\
\hline
\end{tabular}

Table 14. The weight of alternatives.

\begin{tabular}{cccc}
\hline \multirow{2}{*}{ Alternative } & \multicolumn{2}{c}{ Proposed Method } & Fuzzy AHP \\
\cline { 2 - 4 } & Fuzzy Weight Vector & Defuzzy Weights & Weights \\
\hline A & $0.1586,0.1625,0.1705,0.1747$ & 0.161 & 0.146 \\
B & $0.1492,0.1551,0.1626,0.1753$ & 0.153 & 0.155 \\
C & $0.1396,0.1427,0.1490,0.1523$ & 0.147 & 0.143 \\
D & $0.1397,0.1428,0.1489,0.1522$ & 0.141 & 0.139 \\
\hline
\end{tabular}

It should be noted that during the final weighting of the alternatives, as well as calculating the weights of the effective measures on each of the alternatives, the weight of the sub-criteria of the $\mathrm{S}_{\mathrm{C} 1}-\mathrm{S}_{\mathrm{C} 8}$ water pattern modification should be considered for the final weighing of the alternatives. Thus, in Table 14, for calculating the weight of alternatives, the combined effect of effective measures on each alternative and the standard weight of consumption pattern correction criteria has been used. To calculate the normalized weight of alternatives and criteria, fuzzy weight vectors are converted to defuzzy numbers based on Equation (A7). The defuzzy weight values of each criterion are shown in Tables 13 and 14. 
In the next stage, expert opinions converted to fuzzy sets for evaluating the alternatives in relation to each criterion using Table 4 . Then, decision-making opinions are evaluated to get aggregated fuzzy values using Equation (1) that are shown is Table 15.

Table 15. The aggregated fuzzy score of alternatives.

\begin{tabular}{ccc}
\hline Alternative & Criteria & Aggregated Fuzzy Value \\
\hline \multirow{3}{*}{ A } & C1 & $0.226,0.358,0.379,0.524$ \\
& C2 & $0.231,0.365,0.385,0.530$ \\
& C3 & $0.226,0.358,0.380,0.523$ \\
& C4 & $0.238,0.370,0.392,0.534$ \\
& C5 & $0.244,0.379,0.400,0.543$ \\
C6 & $0.228,0.358,0.382,0.523$ \\
\hline \multirow{3}{*}{ B } & C7 & $0.229,0.361,0.383,0.527$ \\
& C8 & $0.244,0.377,0.400,0.542$ \\
& C10 & $0.248,0.382,0.404,0.547$ \\
& C11 & $0.249,0.384,0.406,0.550$ \\
& C12 & $0.247,0.381,0.404,0.546$ \\
& C13 & $0.236,0.369,0.391,0.534$ \\
\hline & C14 & $0.251,0.386,0.408,0.551$ \\
& C15 & $0.249,0.385,0.421,0.561$ \\
& C16 & $0.237,0.370,0.392,0.536$ \\
& C17 & $0.242,0.375,0.397,0.541$ \\
& C18 & $0.262,0.396,0.418,0.559$ \\
\hline D & C19 & $0.230,0.363,0.385,0.530$ \\
& C20 & $0.241,0.373,0.396,0.537$ \\
& C21 & $0.223,0.355,0.376,0.519$ \\
& C22 & $0.235,0.368,0.390,0.533$ \\
& & $0.229,0.361,0.383,0.526$ \\
& & $0.227,0.356,0.380,0.521$ \\
\hline & &
\end{tabular}

Fuzzy decision matrix of alternatives in respect to criteria is calculated using Equation (A8) [66]. Then, the fuzzy decision matrix is normalized using Equations (2-5) [71]. The normalized values are shown in Table 16.

Table 16. Normalized decision matrix.

\begin{tabular}{cccc}
\hline Alternative & Criteria & $\mathbf{u}_{\mathbf{i j}}$ & Defuzzy Value \\
\hline & C1 & $0.390,0.635,0.706,1.00$ & 0.668 \\
& C2 & $0.395,0.641,0.710,1.00$ & 0.677 \\
$\mathbf{A}$ & C3 & $0.393,0.637,0.709,1.00$ & 0.677 \\
& C4 & $0.404,0.645,0.717,1.00$ & 0.677 \\
& C5 & $0.408,0.649,0.719,1.00$ & 0.677 \\
& C6 & $0.395,0.637,0.712,1.00$ & 0.672 \\
\hline \multirow{3}{*}{ B } & C7 & $0.370,0.606,0.675,1.00$ & 0.702 \\
& C8 & $0.384,0.616,0.685,1.00$ & 0.709 \\
& C9 & $0.385,0.617,0.684,1.00$ & 0.700 \\
& C10 & $0.386,0.617,0.684,1.00$ & 0.694 \\
& C11 & $0.385,0.616,0.685,1.00$ & 0.697 \\
& C12 & $0.376,0.611,0.679,1.00$ & 0.708 \\
\hline & C13 & $0.418,0.657,0.724,1.00$ & 0.686 \\
& C14 & $0.430,0.664,0.734,1.00$ & 0.689 \\
& C15 & $0.415,0.655,0.722,1.00$ & 0.688 \\
& C16 & $0.405,0.646,0.715,1.00$ & 0.694 \\
& C17 & $0.409,0.649,0.718,1.00$ & 0.697 \\
& C18 & $0.429,0.664,0.732,1.00$ & 0.689 \\
\hline
\end{tabular}


Table 16. Cont.

\begin{tabular}{cccc}
\hline Alternative & Criteria & $\mathbf{u}_{\mathbf{i j}}$ & Defuzzy Value \\
\hline & C19 & $0.398,0.642,0.711,1.00$ & 0.690 \\
& C20 & $0.411,0.652,0.720,1.00$ & 0.698 \\
D & C21 & $0.395,0.641,0.708,1.00$ & 0.689 \\
& C22 & $0.404,0.647,0.716,1.00$ & 0.694 \\
& C23 & $0.399,0.643,0.712,1.00$ & 0.691 \\
& C24 & $0.400,0.642,0.715,1.00$ & 0.692 \\
\hline
\end{tabular}

In the following, the fuzzy decision matrix and fuzzy importance weight of each criterion are defuzzified using Equation (6) [71]. Defuzzified values are shown in Table 16.

The best and the worst value of defuzzified values of alternatives with respect to each criterion are determined using Equations (8 and 9), and the values are shown in Table 17.

Table 17. The best and worst values of alternative ranking with respect to all criteria.

\begin{tabular}{ccccc}
\hline Alternative & A & B & C & D \\
\hline Best value $\left(f^{*}\right)$ & 0.677 & 0.709 & 0.697 & 0.698 \\
Worst value $\left(f^{-}\right)$ & 0.668 & 0.694 & 0.686 & 0.689 \\
\hline
\end{tabular}

Next, the Utility $\left(S_{j}\right)$, Regret $\left(R_{j}\right)$, and VIKOR indices $\left(Q_{j}\right)$ are calculated using Equations (10-12) [66]. The calculated values are shown in Table 18.

Table 18. The values of $\mathrm{Si}, \mathrm{Ri}$, and VIKOR index for all alternatives.

\begin{tabular}{ccccc}
\hline Alternative & A & B & C & D \\
\hline $\mathrm{S}_{\mathrm{i}}$ & 0.252 & 0.430 & 0.512 & 0.535 \\
$\mathrm{R}_{\mathrm{i}}$ & 0.085 & 0.120 & 0.125 & 0.146 \\
$\mathrm{Q}(\mathrm{v}=0.5)$ & 0.00 & 1.180 & 1.431 & 2.00 \\
\hline
\end{tabular}

In the final step, the ranking of the alternatives is sorted by using each $S_{j}, R_{j}$, and $Q_{i}$ in ascending order, as shown in Table 19. The alternative A with the smallest Qi value is specified to be the best solution.

Table 19. Ranking of the alternatives by VIKOR indices in ascending order.

\begin{tabular}{cccc}
\hline Alternative & $\mathbf{S}_{\mathbf{i}}$ & $\mathbf{R}_{\mathbf{i}}$ & $\mathbf{Q}(\mathbf{v}=\mathbf{0 . 5})$ \\
\hline $\mathrm{A}$ & 1 & 1 & 1 \\
$\mathrm{~B}$ & 2 & 2 & 2 \\
$\mathrm{C}$ & 3 & 3 & 3 \\
$\mathrm{D}$ & 4 & 4 & 4 \\
\hline
\end{tabular}

In this study, both the conditions are fulfilled hence; one of the alternatives with the least VIKOR index is able to be selected as the best alternative. Additionally, it can be seen from the results, in the value range of [0-1], the score of zero represents the most favorable value for a parameter. However, based on the $Q_{i}$ index value, the ranking of the alternatives in ascending order was determined as A, B, C, and D, respectively. Therefore, the A alternative is achieved as the closet alternative to the ideal solution.

In the next section, to obtain the fuzzy evaluation vector, a five-point scale from very high to very low is used for fuzzy evaluation values of decision-makers' opinions related to alternatives and criteria based on trapezoidal fuzzy number. The evaluation vectors are calculated based on the initial evaluation results in Table 12, the fuzzy weight vector (Tables 13 and 14), and using Equation (14) 
for each of the criteria and sub-criteria $\left(\widetilde{f_{j}}\right)$. Then, with the help of the evaluation vectors, the fuzzy evaluation is calculated according to Equation (15). In addition, to obtain the final vector value, the fuzzy evaluation vectors in different hierarchical structures are calculated using Equation (16). The results of the calculations of the fuzzy evaluation vectors are shown in Tables 20 and 21.

Table 20. Calculation of fuzzy evaluation vector for criteria and sub-criteria.

\begin{tabular}{|c|c|c|c|c|}
\hline Alternative & Criteria & The Fuzzy Evaluation Vectors & Rating & Defuzzy Value \\
\hline \multirow{6}{*}{ A } & $\mathrm{C}_{1}$ & $4.14,5.14,6.14,7.14$ & $M, G^{*}$ & 5.643 \\
\hline & $\mathrm{C}_{2}$ & $4.08,5.08,6.08,7.08$ & $\mathrm{M}, \mathrm{G}$ & 5.589 \\
\hline & $\mathrm{C}_{3}$ & $4.14,5.14,6.15,7.14$ & M,G & 5.649 \\
\hline & $\mathrm{C}_{4}$ & $4.05,5.05,6.05,7.05$ & $M, G$ & 5.552 \\
\hline & $\mathrm{C}_{5}$ & $3.98,4.98,5.98,6.98$ & $M, G$ & 5.482 \\
\hline & $\mathrm{C}_{6}$ & $4.14,5.14,6.14,7.14$ & $M, G$ & 5.648 \\
\hline \multirow{6}{*}{ B } & $\mathrm{C}_{7}$ & $4.12,5.12,6.12,7.12$ & M,G & 5.625 \\
\hline & $\mathrm{C}_{8}$ & $3.99,4.99,5.99,6.99$ & $M, G$ & 5.495 \\
\hline & $\mathrm{C}_{9}$ & $3.95,4.95,5.95,6.95$ & M,G & 5.456 \\
\hline & $\mathrm{C}_{10}$ & $3.94,4.94,5.94,6.94$ & $M, G$ & 5.442 \\
\hline & $\mathrm{C}_{11}$ & $3.96,4.96,5.96,6.96$ & $M, G$ & 5.468 \\
\hline & $\mathrm{C}_{12}$ & $4.05,5.05,6.05,7.05$ & M,G & 5.558 \\
\hline \multirow{6}{*}{$\mathrm{C}$} & $\mathrm{C}_{13}$ & $3.92,4.92,5.92,6.92$ & M,G & 5.423 \\
\hline & $\mathrm{C}_{14}$ & $3.83,4.83,5.83,6.83$ & $M, G$ & 5.333 \\
\hline & $\mathrm{C}_{15}$ & $3.93,4.93,5.93,6.93$ & M,G & 5.433 \\
\hline & $\mathrm{C}_{16}$ & $4.05,5.05,6.05,7.05$ & M,G & 5.553 \\
\hline & $\mathrm{C}_{17}$ & $4.01,5.01,6.01,7.01$ & M,G & 5.511 \\
\hline & $\mathrm{C}_{18}$ & $3.845,4.845,5.845,6.845$ & $\mathrm{M}, \mathrm{G}$ & 5.345 \\
\hline \multirow{6}{*}{$\mathrm{D}$} & $\mathrm{C}_{19}$ & $4.11,5.11,6.11,7.11$ & $\mathrm{M}, \mathrm{G}$ & 5.610 \\
\hline & $\mathrm{C}_{20}$ & $4.02,5.02,6.02,7.02$ & M,G & 5.527 \\
\hline & $\mathrm{C}_{21}$ & $4.17,5.17,6.17,7.17$ & $M, G$ & 5.672 \\
\hline & $\mathrm{C}_{22}$ & $4.07,5.07,6.07,7.07$ & $M, G$ & 5.572 \\
\hline & $\mathrm{C}_{23}$ & $4.12,5.12,6.12,7.12$ & $M, G$ & 5.625 \\
\hline & $\mathrm{C}_{24}$ & $4.16,5.16,6.16,7.16$ & M,G & 5.664 \\
\hline \multirow{8}{*}{ Sub-Criteria } & $\mathrm{S}_{\mathrm{C} 1}$ & $4.26,5.26,6.26,7.26$ & $M, G$ & 5.765 \\
\hline & $\mathrm{S}_{\mathrm{C} 2}$ & $4.21,5.21,6.21,7.21$ & M,G & 5.710 \\
\hline & $\mathrm{S}_{\mathrm{C} 3}$ & $4.35,5.35,6.35,7.35$ & M,G & 5.852 \\
\hline & $\mathrm{S}_{\mathrm{C} 4}$ & $3.96,4.96,5.96,6.96$ & M,G & 5.461 \\
\hline & $\mathrm{S}_{\mathrm{C} 5}$ & $3.90,4.90,5.90,6.90$ & $\mathrm{M}, \mathrm{G}$ & 5.401 \\
\hline & $\mathrm{S}_{\mathrm{C} 6}$ & $4.13,5.13,6.13,7.13$ & M,G & 5.636 \\
\hline & $\mathrm{S}_{\mathrm{C} 7}$ & $4.16,5.16,6.16,7.16$ & $M, G$ & 5.665 \\
\hline & $\mathrm{S}_{\mathrm{C} 8}$ & $4.23,5.23,6.23,7.23$ & M,G & 5.639 \\
\hline
\end{tabular}

* $(\mathrm{M}, \mathrm{G})$ : denotes between moderate and good.

Table 21. Calculation of Fuzzy Evaluation Vector for Alternatives.

\begin{tabular}{cccc}
\hline Alternative & The Fuzzy Evaluation Vectors & Rating & Defuzzy Value \\
\hline A & $4.13,4.50,4.88,5.25$ & M,G & 4.70 \\
B & $4.13,4.50,4.88,5.25$ & M,G & 4.69 \\
C & $4.12,4.50,4.87,5.25$ & M,G & 4.68 \\
D & $4.11,4.48,4.86,5.23$ & M,G & 4.67 \\
\hline
\end{tabular}

* (M, G): denotes between moderate and good.

\section{Analysis of the Obtained Results}

The Evaluation of the proper procedure on the role of advertising in modifying water consumption patterns is complicated, and it demonstrated a conflict in decision making due to the existence of diverse criteria and several groups of stakeholders with their own priorities. Therefore, it is not easy 
to recognize an appropriate alternative for decision-makers in order to achieve the optimum one. Based on these problems, fuzzy logic is considered to be an efficient approach to difficult evaluations. According to Tables 20 and 21, the role of mass media on water pattern modification can be analyzed. Membership functions of trapezoidal fuzzy numbers are displayed in 5 levels based on the linguistic variables in Figure 4. In this figure, VP = Very Poor, $\mathrm{P}=$ Poor, $\mathrm{M}=$ Moderate, $\mathrm{G}=\mathrm{Good}, \mathrm{VG}=$ Very Good, and x-axis shows fuzzy value of each level, and y-Axis shows fuzzy membership function of them, which varies from 0 to 1 . Based on the fuzzy evaluation results of the alternative values, the advertising using animation (alternative A) with a membership function in a good and moderate range and the defuzzy value 4.7 has the most critical role in the mass media on modifying the water consumption pattern. Therefore, the results show that there is a positive and significant relationship between advertising using animation and consumption pattern modification; it means that advertising will improve the pattern of water consumption in these cities by increasing advertisement through animation. Additionally, by calculating the weight of each criterion in Table 13, it was determined that among the effective criteria on the advertising using animation, $C_{3}$ and $C_{1}$ criteria with the weights of 0.169 and 0.167 are considered as the most important criteria for choosing alternative $\mathrm{A}$ as the preferred alternative, respectively.

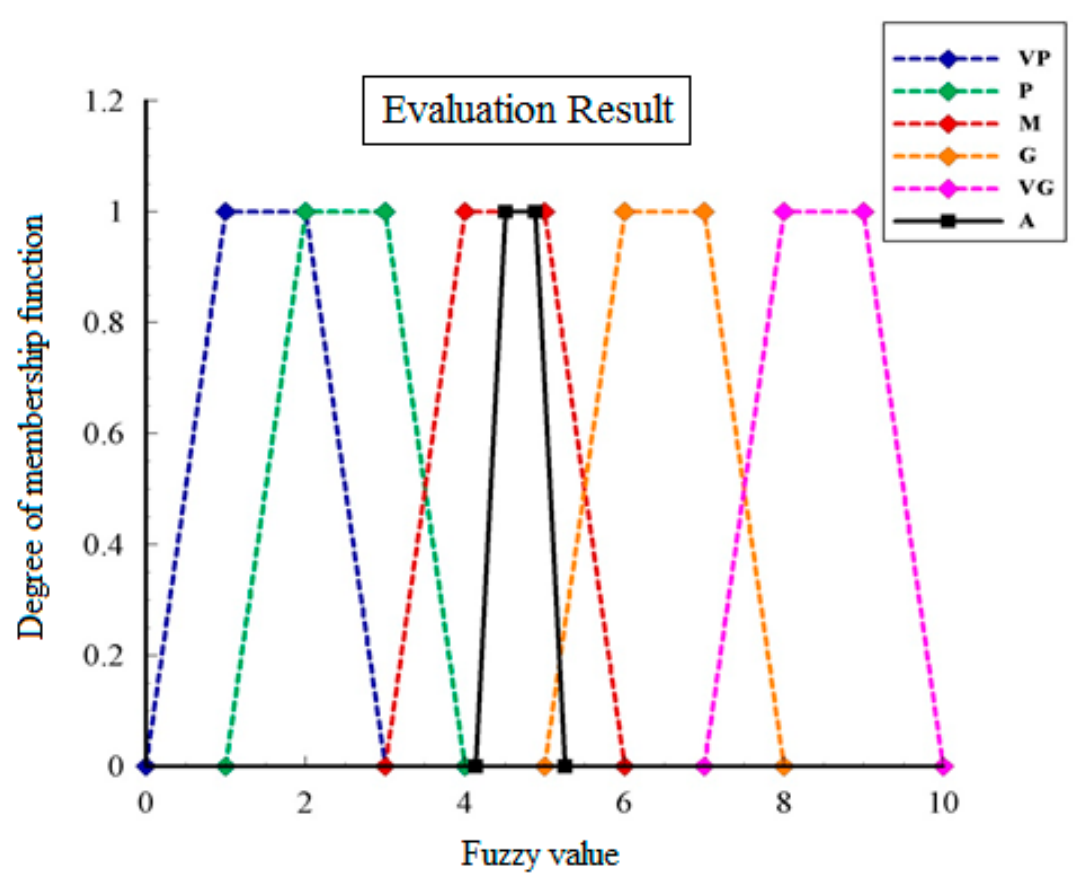

Figure 4. The Membership functions based on linguistic variables and evaluation results.

According to the defuzzy weight values of proposed method (Table 13) and the fuzzy evaluations vector (Table 20), it has been determined that among all sub-criteria, $\mathrm{S}_{\mathrm{C} 3}, \mathrm{~S}_{\mathrm{C} 1}$, and $\mathrm{S}_{\mathrm{C} 2}$ are considered as the most effective ones during the design, respectively. Based on Tables 20 and 21, the advertisement without animation and celebrities (alternative D) with the value 4.67 is considered as the least effective alternative. In addition, the defuzzy evaluation results of criteria are presented in Figure 5. As shown in this Figure, the $C_{14}$ and $C_{18}$ criteria with the values 5.33 and 5.34 are identified as the least important criteria, respectively. Furthermore, among the calculated defuzzy values, the $C_{21}$ criterion with the defuzzy value 6.67 plays an important role to determine the best alternative among all mentioned advertising types on improving the water consumption behavior. Also, among other criteria $\mathrm{C}_{24}(6.66)$, $\mathrm{C}_{6}(6.65), \mathrm{C}_{3}(6.65)$, and $\mathrm{C}_{1}(6.64)$ are ranked next, respectively. 


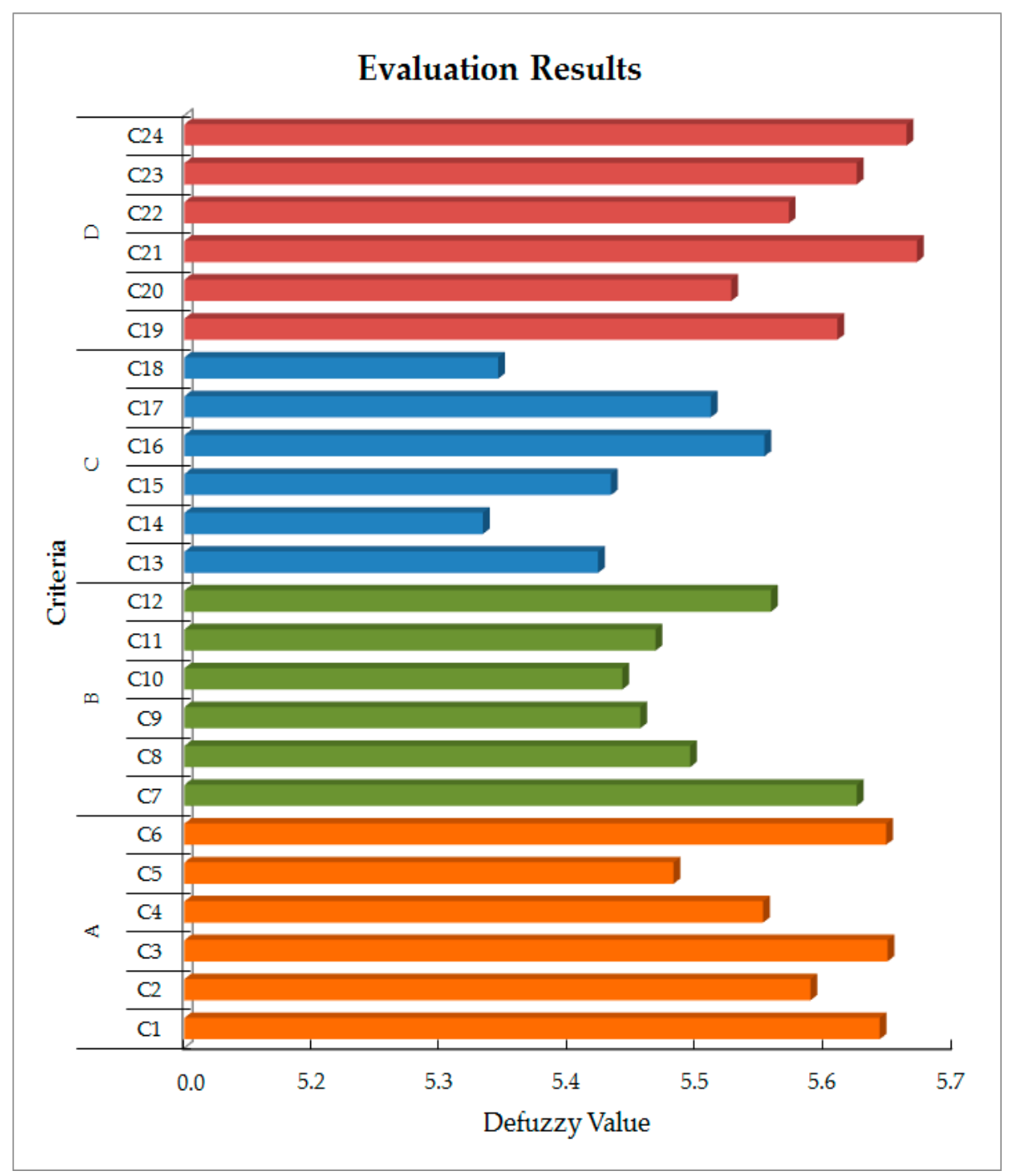

Figure 5. The evaluation of the criteria results.

\section{Discussion}

In the fuzzy AHP method, the pairwise comparison values for calculating the weight of each criterion and alternative using the 9-point Saaty scale [96] that are shown in Table 3. After forming the decision matrices and examining the consistency of those ones, the weight values of each criterion and alternatives were calculated. The results of the importance weight of each criterion and alternatives are presented in Tables 13 and 14. The comparison between the proposed method and the fuzzy AHP method [59] revealed that there is a contradiction between the results of the alternative prioritization in two methods.

In the presented method in this study, the alternative ranking is $A>B>C>D$. Whereas, Fuzzy AHP prioritization is $\mathrm{B}>\mathrm{A}>\mathrm{C}>\mathrm{D}$, and the alternative of advertising with celebrities was introduced as a first priority in reducing water consumption among water consumers.

From these prioritizations, it can be deduced that the fuzzy AHP method is a very useful approach that allows decision-makers to use their judgments about the preference of an alternative and the relative importance of different criteria by using pairwise comparisons and linguistic variables.

However, this method has limited capabilities for evaluating different criteria and alternatives. As the number of options and criteria increases, the AHP method requires complex calculations and the process becomes cumbersome [82]. Therefore, the results of this method will be less accurate. 
Hence, in this study, by applying a fuzzy evaluation method on different criteria and alternatives using a 5-point scale [96], it was found that the results obtained in selecting the ideal solution are consistent with the results of the proposed method.

Therefore, using the fuzzy AHP-VIKOR method is used to find the best alternative among the various types of advertisements to reduce the water consumption pattern.

Moreover, in the proposed method, the weight of the criteria is obtained from the trapezoidal fuzzy number, so that the proposed method gives a more reasonable description of the decision process and reflects more human thinking. For fuzzy AHP, when calculating criteria weights, although linguistic variables are adopted in pairwise comparisons, exact values are used to indicate pairwise comparisons, and the results of the weight are usually presented accurately, which cannot be considered as an advantage of using fuzzy theory [96]. In addition, the proposed method not only can determine the importance weight of different criteria, but also determines the ranking of alternatives in regard to each criterion. On the other hand, since the value of $\mathrm{v}$ plays an important role in the ranking of alternatives [66], a sensitivity analysis was performed to measure the effects of different maximum utility value (v) in the final ranking on the four considered alternatives. The result of the sensitivity analysis is shown in Table 22.

Table 22. Ranking of the alternatives for different value of (v).

\begin{tabular}{ccccccccccccc}
\hline \multirow{2}{*}{$\mathbf{A}_{\mathbf{i}}$} & $\begin{array}{c}\mathbf{Q} \\
\mathbf{( v = 0 . 1 )}\end{array}$ & $\begin{array}{c}\mathbf{Q} \\
\mathbf{( v = 0 . 2 )}\end{array}$ & $\begin{array}{c}\mathbf{Q} \\
\mathbf{( v = 0 . 3 )}\end{array}$ & $\begin{array}{c}\mathbf{Q} \\
\mathbf{( v = 0 . 4 )}\end{array}$ & $\begin{array}{c}\mathbf{Q} \\
\mathbf{( v = 0 . 5 )}\end{array}$ & $\begin{array}{c}\mathbf{Q} \\
\mathbf{( v = 0 . 6 )}\end{array}$ & $\begin{array}{c}\mathbf{Q} \\
\mathbf{( v = 0 . 7 )}\end{array}$ & $\begin{array}{c}\mathbf{Q} \\
\mathbf{( v = 0 . 8 )}\end{array}$ & $\begin{array}{c}\mathbf{Q} \\
\mathbf{( v = 0 . 9 )}\end{array}$ & $\begin{array}{c}\mathbf{Q} \\
\mathbf{( v = 1 . 0 )}\end{array}$ & $\mathbf{R a n k} \mathbf{Q i}$ \\
\hline $\mathbf{A}$ & 0.00 & 0.00 & 0.00 & 0.00 & 0.00 & 0.00 & 0.00 & 0.00 & 0.00 & 0.00 & 1 \\
$\mathbf{B}$ & 0.70 & 0.82 & 0.94 & 1.06 & 1.18 & 1.30 & 1.42 & 1.54 & 1.66 & 1.78 & 2 \\
$\mathbf{C}$ & 0.80 & 0.96 & 1.12 & 1.27 & 1.43 & 1.59 & 1.74 & 1.90 & 2.06 & 2.21 & 3 \\
$\mathbf{D}$ & 1.20 & 1.40 & 1.60 & 1.80 & 2.00 & 2.20 & 2.40 & 2.60 & 2.80 & 3.00 \\
\hline
\end{tabular}

In this analysis, by changing the $\mathrm{v}$ value from 0.1 to 1.0 , the validation of the prioritization results in the proposed method is performed. According to the results of the sensitivity analysis, it was found that the rankings of the alternatives in all the modes were the same as the original rankings, and while changing the value of $\mathrm{v}$ as the "majority of criteria", the position of alternatives in new rankings is stable $[77,78]$.

In addition, based on table $x$, it is illustrated that in all the states of the values of $v$, alternative $A$ has the lowest Qi value of all alternatives. Therefore, based on the aforementioned results, it has been demonstrated that alternative A with the maximum priority is the closest solution to the ideal one. Thus, it is clear from all interpretations that the proposed fuzzy AHP-VIKOR method will be a reliable method of solving complex decision problems.

\section{Conclusions}

Improving the water consumption pattern through institutionalizing the sustainable way to use the precious vital water resource of the country can contribute to improving living standards and reducing costs. The purpose of this study is to investigate the role of different advertising types in modifying the water consumption pattern and consumer behavior of 15 cities located in Iran by utilizing an integrated Fuzzy AHP-VIKOR method. The proposed method is based on a group decision of consumer opinion according to trapezoidal fuzzy numbers to eliminate the level of uncertainty in the data, in which the fuzzy AHP method is used to determine the importance weight of effective criteria. Then, the Fuzzy VIKOR applied to assessment the alternatives priorities. In this method, ADVTs extensions using animation, celebrities, ADVTs on social networks, ADVTs without the use of animation, celebrities, and social networks were discussed as four alternatives for modifying the pattern of water consumption. A total of 24 main criteria and 8 sub-criteria proposed in the questionnaire were considered in the methods of modifying the water consumption pattern. A fuzzy evaluation technique was established to evaluate the ranking reliability of the proposed method. The results of the fuzzy AHP-VIKOR method showed that the vast majority of respondents considered the advertising 
as ineffective without using animation, celebrities, and social networks (alternative D). In other words, the effectiveness of the advertising increased by using animations, and yielded significant changes in the consumers' behavior and the improvement of the water consumption pattern. Finally, the results of the comparison between the method used with the fuzzy AHP method show not only the efficacy and reliability of the applied method, but also in some ways is superior to the fuzzy AHP method. Additionally, a sensitivity analysis is proposed to check the validity of the ranking of the alternatives, which indicates the high effectiveness and reliability of the method.

Author Contributions: Conceptualization: A.H.S., J.M.S.; methodology: A.H.S., A.N., and J.M.S.; software: A.H.S., M.H., A.N.; validation, J.M.S., E.S., H.B., B.G.; formal analysis, A.H.S., A.N., M.A.; data curation, A.H.S., M.H., A.N., M.A.; writing—original draft preparation, A.H.S., E.S., H.B., M.H., M.A., A.N., J.M.S.; writing一review and editing, A.H.S., E.S., M.A., J.M.S.; visualization, A.N. and M.A.; supervision, J.M.S. and H.B. All authors have read and agreed to the published version of the manuscript.

Funding: This research received no external funding.

Acknowledgments: The open access publishing was supported by the BOKU Vienna Open Access Publishing Fund.

Conflicts of Interest: The authors declare no conflict of interest.

\section{Appendix A}

Some basic definitions and operations of fuzzy sets are summarized in this section.

The fuzzy membership function $\mu_{m}$ is obtained from the following Equation A1 [111]:

$$
\mu_{m}(x)= \begin{cases}\frac{x-a}{b-a} & (a \leq x \leq b \\ 1 & (b \leq x \leq c) \\ \frac{d-x}{d-c} & (c \leq x \leq d)\end{cases}
$$

In which $[\mathrm{a}, \mathrm{b}]$ are the values of the intermediate distance of the fuzzy number $\widetilde{m}$, a and $\mathrm{b}$ are the lower and upper limits of the trapezoidal fuzzy number, respectively. It is assumed that $\widetilde{A}$ and $\widetilde{B}$ are two trapezoidal fuzzy numbers that are defined as $\left(a_{1}, a_{2}, a_{3}, a_{4}\right)$ and $\left(b_{1}, b_{2}, b_{3}, b_{4}\right)$. Then, the algebraic calculations of these two trapezoidal fuzzy numbers are calculated as follows Equations (A2)-(A6) [111]:

$$
\begin{gathered}
\widetilde{A} \oplus \widetilde{B}=\left(a_{1}, a_{2}, a_{3}, a_{4}\right) \oplus\left(b_{1}, b_{2}, b_{3}, b_{4}\right)=\left(a_{1}+b_{1}, a_{2}+b_{2}, a_{3}+b_{3}, a_{4}+b_{4}\right) \\
\widetilde{A}-\widetilde{B}=\left(a_{1}, a_{2}, a_{3}, a_{4}\right)-\left(b_{1}, b_{2}, b_{3}, b_{4}\right)=\left(a_{1}-b_{1}, a_{2}-b_{2}, a_{3}-b_{3}, a_{4}-b_{4}\right) \\
\widetilde{A} \otimes \widetilde{B}=\left(a_{1}, a_{2}, a_{3}, a_{4}\right) \otimes\left(b_{1}, b_{2}, b_{3}, b_{4}\right)=\left(a_{1} b_{1}, a_{2} b_{2}, a_{3} b_{3}, a_{4} b_{4}\right) \\
k \widetilde{A}=\left(k a_{1}, k a_{2}, k a_{3}, k a_{4}\right) \\
\widetilde{A}^{-1}=\left(\frac{1}{a_{4}}, \frac{1}{a_{3}}, \frac{1}{a_{2}}, \frac{1}{a_{1}}\right)
\end{gathered}
$$

To convert a trapezoidal fuzzy number to defuzzy values, it is necessary to have a defuzzification action. It is assumed that $\widetilde{A}=(a, b, c, d)$ is a trapezoidal fuzzy number. Thus, the exact amount of this fuzzy number is obtained by the following Equation (A7) [115].

$$
N=\frac{(b-c)}{2}+[(d-c)-(b-a)]+\frac{(a+2 b+2 c+d)}{6}
$$

where $N$ is the determined value of the trapezoidal fuzzy number.

\section{Appendix B}

Fuzzy AHP to determine weight of criteria: 
In this paper, AHP method is used to aggregate individual opinions and compute importance weight of each criterion. The procedure of the Fuzzy AHP is described as follows:

Forming the hierarchical decision tree:

In this step, the hierarchy decision structure is drawn using the target level criterion and alternative.

Formation of a pairwise comparison matrix:

The fuzzy AHP method is often used to represent pairwise comparison matrix values of the Saaty scale [96] based on trapezoidal numbers (see Table 3).

The matrix $\widetilde{X}$ is based on a pairwise comparison of criteria and is by Equation (A8).

$$
\widetilde{X}=\left[\begin{array}{cccc}
\widetilde{x}_{11} & \widetilde{x}_{12} & \cdots & \widetilde{x}_{1 n} \\
\widetilde{x}_{21} & \widetilde{x}_{22} & \cdots & \widetilde{x}_{2 n} \\
\vdots & \vdots & \cdots & \vdots \\
\widetilde{x}_{n 1} & \widetilde{x}_{n 2} & & \widetilde{x}_{n n}
\end{array}\right]
$$

where $x^{i j}$ is the paired comparison of the $i^{\text {th }}$ criterion relative to the $j^{\text {th }}$ criterion. If the paired comparison of criterion $i$ is equal to $j$, then this value can be equal to the inverse of $x_{i j}{ }^{-1}$, which is shown in Equations (A9 and A10).

$$
\begin{gathered}
\tilde{x}_{i j}=\left(l_{i j}, m_{i j}, n_{i j}, s_{i j}\right) \\
\widetilde{x}_{i j}=\left(\widetilde{x}_{i j}\right)^{-1}=\left(s_{i j}^{-1}, n_{i j}^{-1}, m_{i j}^{-1}, l_{i j}^{-1}\right)
\end{gathered}
$$

Calculating data Consistency

Inconsistency ratio of hierarchy process is a mechanism through which the validity of decision-makers' response to the questioner is evaluated with paired comparisons. Any error and inconsistency in comparison of determination of alternatives' importance and criteria will disrupt the outputs.

Before calculating the weight of the criteria, the inconsistency of the pairwise comparison matrices should be checked. The interested readers are referring to Appendix A for more details regarding how to achieve the inconsistency of the comparison matrix. Based on Equation (A7) (Appendix A), the fuzzy values should be converted to defuzzy values, and then this defuzzy matrix of criteria is given as $X=\left[x_{i j}\right], i=1, \ldots, n, j=1, \ldots, m$.

Hence, the comparison of the inconsistency rate of a comparison matrix $\mathrm{X}$ is calculated as follows:

First, the maximum eigenvalue of the matrix according to the following Equation (A11) is obtained [116]:

$$
X w=\lambda_{\max } w
$$

where $\mathrm{w}$ is the weight vector of the comparison matrix.

Based on the following Equations (A12) and (A13), the consistency ratio (C.R) is calculated by dividing the consistency index (C.I) on the random index (R.I):

$$
\begin{gathered}
\text { C.R }=\text { C.I } / \text { R.I } \\
\text { C.I }=\left(\lambda_{\max }-n\right) /(n-1)
\end{gathered}
$$

Determining the initial data evaluation for decision elements:

Each member in the decision committee should assign the evaluation score for each criterion and sub-criterion.

Calculation of the weight vector: 
Based on the pairwise comparison matrix $\widetilde{X}$, the aggregated fuzzy weight of criteria can be calculated with Equations (A14-A16) [98]:

$$
\left\{\begin{array}{l}
\alpha=\sum_{j=1}^{n} \alpha_{j}, \alpha_{j}=\left[\prod_{j=1}^{n} l_{i j}\right]^{1 / n} \\
\beta=\sum_{j=1}^{n} \beta_{j}, \beta_{j}=\left[\prod_{j=1}^{n} m_{i j}\right]^{1 / n} \\
\gamma=\sum_{j=1}^{n} \gamma_{j}, \gamma_{j}=\left[\prod_{j=1}^{n} n_{i j}\right]^{1 / n} \\
\delta=\sum_{j=1}^{n} \delta_{j}, \delta_{j}=\left[\prod_{j=1}^{n} s_{i j}\right]^{1 / n}
\end{array}\right.
$$

Then the weights can be calculated with the Equation (A15),

$$
\widetilde{w}_{j}=\left(\alpha_{j} \delta^{-1}, \beta_{j} \gamma^{-1}, \gamma_{j} \beta^{-1}, \delta_{j} \alpha^{-1}\right), j \in\{1,2, \ldots n\}
$$

The fuzzy weight vector is also obtained in the form of Equation (A16),

$$
\widetilde{W}=\left[\widetilde{w}_{1}, \widetilde{w}_{2}, \ldots, \widetilde{w}_{n}\right]
$$

\section{References}

1. Vafaeifard, M.; Lee, G.; Akib, S.; Ibrahim, S.; Yoon, Y.; Jang, M. Facile and economic one-pot synthesis of rigid functional-polyurethane for the effective treatment of heavy metal-contaminated urban storm water run-off. Desalin. Water Treat. 2016, 57, 26114-26129. [CrossRef]

2. Salimi, A.; Karami, H.; Farzin, S.; Hassanvand, M.; Azad, A.; Kisi, O. Design of water supply system from rivers using artificial intelligence to model water hammer. ISH J. Hydraul. Eng. 2019, 20, 1-10. [CrossRef]

3. Salimi, A.H.; Masoompour Samakosh, J.; Sharifi, E.; Hassanvand, M.R.; Noori, A.; von Rautenkranz, H. Optimized Artificial Neural Networks-Based Methods for Statistical Downscaling of Gridded Precipitation Data. Water 2019, 11, 1653. [CrossRef]

4. Salimi, A.H.; Mousavi, S.F.; Farzin, S. Removal of sulfate from Gamasiab river water samples by using natural nano-Clinoptilolite. J. Appl. Res. Water Wastewater 2019, 6, 39-44. [CrossRef]

5. Sharifi, E.; Eitzinger, J.; Dorigo, W. Performance of the State-Of-The-Art Gridded Precipitation Products over Mountainous Terrain: A Regional Study over Austria. Remote Sens. 2019, 11, 2018. [CrossRef]

6. Sharifi, E.; Saghafian, B.; Steinacker, R. Copula-based stochastic uncertainty analysis of satellite precipitation products. J. Hydrol. 2019, 570, 739-754. [CrossRef]

7. Abouzari, N.; Hassanvand, M.; Salimi, A.; Heddam, S.; Omidvar Mohammadi, H.; Noori, A. Comparison performance of artificial neural network based method in estimation of electric conductivity in wet and dry periods: Case study of Gamasiab River, Iran. J. Appl. Res. Water Wastewater 2019. [CrossRef]

8. Salami, A.H.; Bonakdari, H.; Akhbari, A.; Shamshiri, A.; Mousavi, S.F.; Farzin, S.; Hassanvand, M.; Noori, A. Performance assessment of modified clinoptilolite and magnetic nanotubes on sulfate removal and potential application in natural river samples. J. Incl. Phenom. Macrocycl. Chem. 2020. [CrossRef]

9. Dupont, D.; Waldner, C.; Bharadwaj, L.; Plummer, R.; Carter, B.; Cave, K.; Zagozewski, R. Drinking water management: Health risk perceptions and choices in First Nations and non-First Nations communities in Canada. Int. J. Environ. Res. Public Health 2014, 11, 5889-5903. [CrossRef]

10. Patrick, R.J. Uneven access to safe drinking water for First Nations in Canada: Connecting health and place through source water protection. Health Place 2011, 17, 386-389. [CrossRef] [PubMed]

11. Kaklauskas, A.; Zavadskas, E.K.; Radzeviciene, A.; Ubarte, I.; Podviezko, A.; Podvezko, V.; Kuzminske, A.; Banaitis, A.; Binkyte, A.; Bucinskas, V. Quality of city life multiple criteria analysis. Cities 2018, 72, 82-93. [CrossRef] 
12. Abrahams, N.A.; Hubbell, B.J.; Jordan, J.L. Joint Production and Averting Expenditure Measures of Willingness to Pay: Do Water Expenditures Really Measure Avoidance Costs? Am. J. Agric. Econ. 2000, 82, 427-437. [CrossRef]

13. Siddiqi, A.; Anadon, L.D. The water-energy nexus in Middle East and North Africa. Energy Policy 2011, 39, 4529-4540. [CrossRef]

14. Qasemipour, E.; Abbasi, A. Assessment of Agricultural Water Resources Sustainability in Arid Regions Using Virtual Water Concept: Case of South Khorasan Province, Iran. Water 2019, 11, 449. [CrossRef]

15. Smith, A.; Paterson, R. Television: An International History, 2nd ed.; Anthony, S., Ed.; Oxford University Press: Oxford, UK, 1998; ISBN 9780198159285.

16. Amoateng, K.; Amoako-Adu, B. Economic growth, export and external debt causality: The case of African countries. Appl. Econ. 1996, 28, 21-27. [CrossRef]

17. Ozernoy, V.M. Choosing The "Best" Multiple Criterlv Decision-Making Method. INFOR Inf. Syst. Oper. Res. 1992, 30, 159-171. [CrossRef]

18. Despontin, M.; Moscarola, J.; Spronk, J. A user-oriented listing of multiple criteria decision methods. Rev. Belg. Stat. Inform. Rech. Opérationalle 1983, 23, 4-110.

19. Dağdeviren, M.; Yüksel, İ. Developing a fuzzy analytic hierarchy process (AHP) model for behavior-based safety management. Inf. Sci. 2008, 178, 1717-1733. [CrossRef]

20. Aryanejad, M.B.; Ghavampour, S. Two Stage Multiple Attribute Decision Making Problem in Iranian Gas Distribution Systems. Int. J. Eng. 2004, 17, 135-144.

21. Ramkumar, M. A modified ANP and fuzzy inference system based approach for risk assessment of in-house and third party e-procurement systems. Strateg. Outsourcing Int. J. 2016, 9, 159-188. [CrossRef]

22. Zegordi, S.H.; Rezaee Nik, E.; Nzari, A. Power Plant Project Risk Assessment Using a Fuzzy-ANP and Fuzzy-TOPSIS Method. Int. J. Eng. 2012, 25, 107-120. [CrossRef]

23. Saaty, T.L. Decision making with the analytic hierarchy process. Int. J. Serv. Sci. 2008, 1, 83. [CrossRef]

24. Yoon, K.P.; Hwang, C.L. Multiple Attribute Decision Making: An Introduction; Sage Publications, Inc.: Thousand Oaks, CA, USA, 1995; ISBN 0-8039-5486-7.

25. Mousavi, S.M. A Multi-Criteria Decision-Making Approach with Interval Numbers for Evaluating Project Risk Responses. Int. J. Eng. 2012, 25, 121-129. [CrossRef]

26. Roy, B. Classement et choix en présence de points de vue multiples. RAIRO-Oper. Res.-Rech. Opérationnelle. 1968, 2, 57-75. [CrossRef]

27. Ramkumar, M.; Jenamani, M. E-procurement service provider selection-An analytic network process-based group decision-making approach. Serv. Sci. 2012, 4, 269-294. [CrossRef]

28. Saaty, T.L.; Alexander, J.M. Thinking with Models: Mathematical Models in the Physical, Biological, and Social Sciences; RWS Publications: Pittsburgh, PA, USA, 1981; ISBN 978-1-888603-41-5.

29. Opricovic, S.; Tzeng, G.H. Multicriteria Planning of Post-Earthquake Sustainable Reconstruction. Comput.-Aided Civ. Infrastruct. Eng. 2002, 17, 211-220. [CrossRef]

30. Brans, J.P.; Mareschal, B. PROMETHEE methods. In Multiple Criteria Decision Analysis: State of the Art Surveys; Springer: New York, NY, USA, 2005; pp. 163-186. [CrossRef]

31. Egilmez, G.; Gumus, S.; Kucukvar, M. Environmental sustainability benchmarking of the U.S. and Canada metropoles: An expert judgment-based multi-criteria decision making approach. Cities 2015, 42, 31-41. [CrossRef]

32. Noori, A.; Bonakdari, H.; Morovati, K.; Gharabaghi, B. The optimal dam site selection using a group decision-making method through fuzzy TOPSIS model. Environ. Syst. Decis. 2018, 38, 471-488. [CrossRef]

33. Manupati, V.K.; Ramkumar, M.; Samanta, D. A multi-criteria decision making approach for the urban renewal in Southern India. Sustain. Cities Soc. 2018, 42, 471-481. [CrossRef]

34. Noori, A.; Bonakdari, H.; Salimi, A.; Hassanvand, M. Investigating an Optimal Water Supply approach for the Gamasiab basin using the fuzzy extended Analytic Hierarchy Process method. J. Appl. Res. Water Wastewater 2020. [CrossRef]

35. Saaty, T.L.; Vargas, L.G. Models, Methods, Concepts \& Applications of the Analytic Hierarchy Process; Springer: New York, NY, USA, 2012; ISBN 978-1-4614-3597-6.

36. Yücenur, G.N.; Demirel, N.Ç. Group decision making process for insurance company selection problem with extended VIKOR method under fuzzy environment. Expert Syst. Appl. 2012, 39, 3702-3707. [CrossRef] 
37. Opricovic, S.; Tzeng, G.H. Extended VIKOR method in comparison with outranking methods. Eur. J. Oper. Res. 2007, 178, 514-529. [CrossRef]

38. Opricovic, S. Multicriteria Optimization of Civil Engineering Systems. Ph.D. Thesis, Faculty of Civil Engineering, Belgrade, Serbia, 1998.

39. Opricovic, S. Fuzzy VIKOR with an application to water resources planning. Expert Syst. Appl. 2011, 38, 12983-12990. [CrossRef]

40. Voskoglou, M.G. Assessment of Human Skills Using Trapezoidal Fuzzy Numbers (Part II). Am. J. Comput. Appl. Math. 2015, 5, 154-158.

41. Rodcha, R.; Tripathi, N.K.; Prasad Shrestha, R. Comparison of Cash Crop Suitability Assessment Using Parametric, AHP, and FAHP Methods. Land 2019, 8(5), 79. [CrossRef]

42. Popkin, B.M.; Barclay, D.V.; Nielsen, S.J. Water and food consumption patterns of US adults from 1999 to 2001. Obes. Res. 2005, 13, 2146-2152. [CrossRef]

43. Keshavarzi, A.R.; Sharifzadeh, M.; Haghighi, A.K.; Amin, S.; Keshtkar, S.; Bamdad, A. Rural domestic water consumption behavior: A case study in Ramjerd area, Fars province, IR Iran. Water Res. 2006, 40, 1173-1178. [CrossRef]

44. Jones, A.Q.; Majowicz, S.E.; Edge, V.L.; Thomas, M.K.; MacDougall, L.; Fyfe, M.; Atashband, S.; Kovacs, S.J. Drinking water consumption patterns in British Columbia: An investigation of associations with demographic factors and acute gastrointestinal illness. Sci. Total Environ. 2007, 388, 54-65. [CrossRef]

45. Harlan, S.L.; Yabiku, S.T.; Larsen, L.; Brazel, A.J. Household water consumption in an arid city: Affluence, affordance, and attitudes. Soc. Nat. Resour. 2009, 22, 691-709. [CrossRef]

46. Islam, M.A.; Sakakibara, H.; Karim, M.R.; Sekine, M. Rural water consumption behavior: A case study in southwest coastal area, Bangladesh. In Proceedings of the World Environmental and Water Resources Congress 2011: Bearing Knowledge for Sustainability, 22-26 May 2011; pp. 4403-4412.

47. Shan, Y.; Yang, L.; Perren, K.; Zhang, Y. Household water consumption: Insight from a survey in Greece and Poland. Procedia Eng. 2015, 119, 1409-1418. [CrossRef]

48. Wright, C.J.; Sargeant, J.M.; Edge, V.L.; Ford, J.D.; Farahbakhsh, K.; Shiwak, I.; Flowers, C.; Gordon, A.C.; Harper, S.L.; IHACC Research Team. How are perceptions associated with water consumption in Canadian Inuit? A cross-sectional survey in Rigolet, Labrador. Sci. Total Environ. 2018, 618, 369-378. [CrossRef] [PubMed]

49. Breuer, R.; Brettel, M.; Engelen, A. Incorporating long-term effects in determining the effectiveness of different types of online advertising. Mark. Lett. 2011, 22, 327-340. [CrossRef]

50. Hsieh, Y.C.; Chen, K.H. How different information types affect viewer's attention on internet advertising. Comput. Hum. Behav. 2011, 27, 935-945. [CrossRef]

51. Amoateng, F.; Poku, K. The Impact of Advertisement on Alcohol Consumption: A Case Study of Consumers in Bantama Sub-Metro. Int. Rev. Manag. Mark. 2012, 3, 28-36.

52. Srikanth, J.; Saravanakumar, M.; Srividhya, S. The impact of celebrity advertisement on Indian customers. Life Sci. J. 2013, 10, 59-65.

53. Ramkumar, M.; Jenamani, M. Sustainability in supply chain through e-procurement-An assessment framework based on DANP and liberatore score. IEEE Syst. J. 2014, 9, 1554-1564. [CrossRef]

54. Nomura, T.; Mitsukura, Y. EEG-based detection of TV commercials effects. Procedia Comput. Sci. 2015, 60, 131-140. [CrossRef]

55. Gilbert-Diamond, D.; Emond, J.A.; Lansigan, R.K.; Rapuano, K.M.; Kelley, W.M.; Heatherton, T.F.; Sargent, J.D. Television food advertisement exposure and FTO rs9939609 genotype in relation to excess consumption in children. Int. J. Obes. 2017, 41, 23. [CrossRef]

56. Wang, R.; Liaukonyte, J.; Kaiser, H.M. Does Advertising Content Matter? Impacts of Healthy Eating and Anti-Obesity Advertising on Willingness to Pay by Consumer Body Mass Index. Agric. Resour. Econ. Rev. 2018, 1-31. [CrossRef]

57. Van Laarhoven, P.J.M.; Pedrycz, W. A fuzzy extension of Saaty's priority theory. Fuzzy Sets Syst. 1983, 11, 229-241. [CrossRef]

58. Buckley, J. Fuzzy hierarchical analysis. Fuzzy Sets Syst. 1985, 17, 233-247. [CrossRef]

59. Chang, D.-Y. Applications of the extent analysis method on fuzzy AHP. Eur. J. Oper. Res. 1996, 95, 649-655. [CrossRef] 
60. Cheng, C.-H. Evaluating naval tactical missile systems by fuzzy AHP based on the grade value of membership function. Eur. J. Oper. Res. 1997, 96, 343-350. [CrossRef]

61. Deng, H. Multicriteria analysis with fuzzy pairwise comparison. Int. J. Approx. Reason. 1999, 21, $215-231$. [CrossRef]

62. Csutora, R.; Buckley, J.J. Fuzzy hierarchical analysis: The Lambda-Max method. Fuzzy Sets Syst. 2001, 120, 181-195. [CrossRef]

63. Wang, Y.-M.; Chin, K.-S. An eigenvector method for generating normalized interval and fuzzy weights. Appl. Math. Comput. 2006, 181, 1257-1275. [CrossRef]

64. Lee, S.-H. Using fuzzy AHP to develop intellectual capital evaluation model for assessing their performance contribution in a university. Expert Syst. Appl. 2010, 37, 4941-4947. [CrossRef]

65. Goyal, R.K.; Kaushal, S.; Sangaiah, A.K. The utility based non-linear fuzzy AHP optimization model for network selection in heterogeneous wireless networks. Appl. Soft Comput. 2018, 67, 800-811. [CrossRef]

66. Opricovic, S.; Tzeng, G.-H. Compromise solution by MCDM methods: A comparative analysis of VIKOR and TOPSIS. Eur. J. Oper. Res. 2004, 156, 445-455. [CrossRef]

67. Liou, J.J.H.; Tsai, C.Y.; Lin, R.H.; Tzeng, G.H. A modified VIKOR multiplecriteria decision method for improving domestic airlines service quality. J. Air Transp. Manag. 2010, 1-5. [CrossRef]

68. Sanayei, A.; Mousavi, S.F.; Yazdankhah, A. Group decision making process for supplier selection with VIKOR under fuzzy environment. Expert Syst. Appl. 2010, 37, 24-30. [CrossRef]

69. Ying-Yu, W.; De-Jian, Y. Extended VIKOR for multi-criteria decision making problems under intuitionistic environment. In Proceedings of the 2011 International Conference on Management Science \& Engineering 18th Annual Conference Proceedings, Rome, Italy, 13-15 September 2011; pp. 118-122.

70. Tiwari, V.; Jain, P.K.; Tandon, P. Product design concept evaluation using rough sets and VIKOR method. Adv. Eng. Inform. 2016, 30, 16-25. [CrossRef]

71. Shemshadi, A.; Shirazi, H.; Toreihi, M.; Tarokh, M. A fuzzy VIKOR method for supplier selection based on entropy measure for objective weighting. Expert Syst. Appl. 2011, 38, 12160-12167. [CrossRef]

72. Wang, T.C.; Chang, T.H. Fuzzy VIKOR as a resolution for multicriteria group decision-making. In Proceedings of the 11th International Conference on Industrial Engineering and Engineering Management (IEEM 2005), Shenyang, China, 23-25 April 2005.

73. Chang, C.-L.; Hsu, C.-H. Multi-criteria analysis via the VIKOR method for prioritizing land-use restraint strategies in the Tseng-Wen reservoir watershed. J. Environ. Manag. 2009, 90, 3226-3230. [CrossRef]

74. San Cristóbal, J.R. Multi-criteria decision-making in the selection of a renewable energy project in spain: The Vikor method. Renew. Energy 2011, 36, 498-502. [CrossRef]

75. Kavita, D. Extension of VIKOR method in intuitionistic fuzzy environment for robot selection. Expert Syst. Appl. 2011, 38, 14163-14168.

76. Kaya, T.; Kahraman, C. Multicriteria renewable energy planning using an integrated fuzzy VIKOR \& AHP methodology: The case of Istanbul. Energy 2010, 35, 2517-2527.

77. Zhu, G.-N.; Hu, J.; Qi, J.; Gu, C.-C.; Peng, Y.-H. An integrated AHP and VIKOR for design concept evaluation based on rough number. Adv. Eng. Informatics 2015, 29, 408-418. [CrossRef]

78. Singh, S.; Olugu, E.U.; Musa, S.N.; Mahat, A.B.; Wong, K.Y. Strategy selection for sustainable manufacturing with integrated AHP-VIKOR method under interval-valued fuzzy environment. Int. J. Adv. Manuf. Technol. 2016, 84, 547-563. [CrossRef]

79. Rezaie, K.; Ramiyani, S.S.; Nazari-Shirkouhi, S.; Badizadeh, A. Evaluating performance of Iranian cement firms using an integrated fuzzy AHP-VIKOR method. Appl. Math. Model. 2014, 38, 5033-5046. [CrossRef]

80. Kaya, T.; Kahraman, C. Fuzzy multiple criteria forestry decision making based on an integrated VIKOR and AHP approach. Expert Syst. Appl. 2011, 38, 7326-7333. [CrossRef]

81. Zamani, S.; Farughi, H.; Soolaki, M. Contractor selection using fuzzy hybrid AHP-VIKOR. Int. J. Res. Ind. Eng. 2014, 2, 26-40.

82. Pourebrahim, S.; Hadipour, M.; Bin Mokhtar, M.; Taghavi, S. Application of VIKOR and fuzzy AHP for conservation priority assessment in coastal areas: Case of Khuzestan district, Iran. Ocean Coast. Manag. 2014, 98, 20-26. [CrossRef]

83. Fu, H.-P.; Chu, K.-K.; Chao, P.; Lee, H.-H.; Liao, Y.-C. Using fuzzy AHP and VIKOR for benchmarking analysis in the hotel industry. Serv. Ind. J. 2011, 31, 2373-2389. [CrossRef] 
84. Mohaghar, A.; Fathi, M.R.; Zarchi, M.K.; Omidian, A. A combined VIKOR-fuzzy AHP approach to marketing strategy selection. Bus. Manag. Strategy 2012, 3, 13-27. [CrossRef]

85. Awasthi, A.; Govindan, K.; Gold, S. Multi-tier sustainable global supplier selection using a fuzzy AHP-VIKOR based approach. Int. J. Prod. Econ. 2018, 195, 106-117. [CrossRef]

86. Sanjani, S.; Bannayan, M.; Kamyabnejad, M. Detection of recent climate change using daily temperature extremes in Khorasan Province, Iran. Clim. Res. 2011, 49, 247-254. [CrossRef]

87. Census. Census of the Islamic Republic of Iran. 2011. Available online: http:.irandataportal.syr.edu.2011census (accessed on 6 February 2020).

88. Brown, N.; Deegan, C. The public disclosure of environmental performance information-a dual test of media agenda setting theory and legitimacy theory. Account. Bus. Res. 1998, 29, 21-41. [CrossRef]

89. Weaver, D.H. Thoughts on Agenda Setting, Framing, and Priming. J. Commun. 2007, 57, 142-147. [CrossRef]

90. Shrum, L.J. Assessing the Social Influence of Television. Commun. Res. 1995, 22, 402-429. [CrossRef]

91. Miller, K. Communication theories. In Perspectives, Processes, and Contexts, 2nd ed.; McGraw-Hill: Boston, CA, USA, 2005; ISBN 9780071238359.

92. Bandura, A. Social Learning Theory; Prentice-Hall: London, UK, 1977; ISBN 0138167516.

93. Khang, H.; Ki, E.-J.; Ye, L. Social Media Research in Advertising, Communication, Marketing, and Public Relations, 1997-2010. Journal. Mass Commun. Q. 2012, 89, 279-298. [CrossRef]

94. Argyris, C.; Schön, D.A. Theory in practice. In Increasing Professional Effectiveness; Chris, A., Donald, A.S., Eds.; Josey-Bass: San Francisco, CA, USA, 1974; ISBN 978-1555424466.

95. Saaty, T.L. How to make a decision: The analytic hierarchy process. Eur. J. Oper. Res. 1990, 48, 9-26. [CrossRef]

96. Mou, Q. Method of Multi-Attribute Decision-Making and Its Application; Guangxi University: Nanning, China, 2004.

97. Zheng, G.; Zhu, N.; Tian, Z.; Chen, Y.; Sun, B. Application of a trapezoidal fuzzy AHP method for work safety evaluation and early warning rating of hot and humid environments. Saf. Sci. 2012, 50, 228-239. [CrossRef]

98. Xia, H.-C.; Li, D.-F.; Zhou, J.-Y.; Wang, J.-M. Fuzzy LINMAP method for multiattribute decision making under fuzzy environments. J. Comput. Syst. Sci. 2006, 72, 741-759. [CrossRef]

99. Vakratsas, D.; Ambler, T. How Advertising Works: What Do We Really Know? J. Mark. 1999, 63, $26-43$. [CrossRef]

100. Cleeren, G.; Quirynen, M.; Ozcelik, O.; Teughels, W. Role of 3D animation in periodontal patient education: A randomized controlled trial. J. Clin. Periodontol. 2014, 41, 38-45. [CrossRef]

101. Cronley, M.L.; Kardes, F.R.; Goddard, P.; Houghton, D.C. Endorsing Products For the Money: The Role of the Correspondence Bias in Celebrity Advertising. ACR N. Am. Adv. 1999, 26, 627-631.

102. Fleck, N.; Korchia, M.; Le Roy, I. Celebrities in Advertising: Looking for Congruence or Likability? Psychol. Mark. 2012, 29, 651-662. [CrossRef]

103. Lenhart, A.; Purcell, K.; Smith, A.; Zickuhr, K. Social Media E Mobile Internet Use among Teens and Young Adults; Millennials, Pew internet \& American Life Project: Washington, DC, USA, 2010.

104. Chow, W.S.; Chan, L.S. Social network, social trust and shared goals in organizational knowledge sharing. Inf. Manag. 2008, 45, 458-465. [CrossRef]

105. Boyd, D. Why Youth Heart Social Network Sites: The Role of Networked Publics in Teenage Social Life. In YOUTH, IDENTITY, AND DIGITAL MEDIA, David Buckingham; MacArthur Foundation Series on Digital Media and Learning; John, D., Catherine, T., Eds.; The MIT Press: Cambridge, MA, USA, 2017; pp. 2007-2016.

106. Sæbø, Ø.; Rose, J.; Nyvang, T. The Role of Social Networking Services in eParticipation. In Post-Quantum Cryptography; Springer Science and Business Media: Berlin/Heidelberg, Germany, 2009; Volume 5694, pp. 46-55.

107. Nielsen, A.E.; Thomsen, C. Sustainable development: The role of network communication. Corp. Soc. Responsib. Environ. Manag. 2011, 18,1-10. [CrossRef]

108. Messner, D. The Network Society: Economic Development and International Competitveness as Problems of Social; Routledge: Abington, UK, 2013; ISBN 9781315036946.

109. Joy, A.; Sherry, J.F.; Deschênes, J. Conceptual blending in advertising. J. Bus. Res. 2009, 62, 39-49. [CrossRef]

110. Rozendaal, E.; Lapierre, M.A.; Van Reijmersdal, E.A.; Buijzen, M. Reconsidering Advertising Literacy as a Defense Against Advertising Effects. Media Psychol. 2011, 14, 333-354. [CrossRef] 
111. Sadi-Nezhad, S.; Damghani, K.K. Application of a fuzzy TOPSIS method base on modified preference ratio and fuzzy distance measurement in assessment of traffic police centers performance. Appl. Soft Comput. 2010, 10, 1028-1039. [CrossRef]

112. Wang, T.-C.; Liang, J.-L.; Ho, C.-Y. Multi-Criteria Decision Analysis by Using Fuzzy VIKOR. In Proceedings of the 2006 International Conference on Service Systems and Service Management, Troyes, France, 25-27 October 2006; pp. 901-906.

113. Zeleny, M. Multiple Criteria Decision Making; McGraw-Hill: New York, NY, USA, 1982.

114. Yu, P.L. A Class of Solutions for Group Decision Problems. Manag. Sci. 1973, 19, 936-946. [CrossRef]

115. Lin, H.F.; Lee, G.G. A study of service quality evaluation model for virtual knowledge communities. Electron. Commer. Stud. 2006, 4, 211-234.

116. Yao, Y.; Lian, Z.; Liu, S.; Hou, Z. Hourly cooling load prediction by a combined forecasting model based on Analytic Hierarchy Process. Int. J. Therm. Sci. 2004, 43, 1107-1118. [CrossRef]

(C) 2020 by the authors. Licensee MDPI, Basel, Switzerland. This article is an open access article distributed under the terms and conditions of the Creative Commons Attribution (CC BY) license (http://creativecommons.org/licenses/by/4.0/). 